\title{
Energy applications and studies for healthcare facilities- a systematic literature review
}

\author{
Sağlık hizmet binalarında enerji uygulamaları ve çalışmaları: sistematik bir \\ literatür çalıșması
}

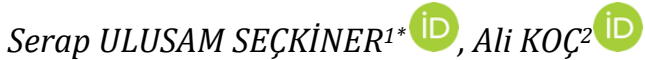 \\ 1,2Industrial Engineering Department, Faculty of Engineering, Gaziantep University, Gaziantep, Turkey. \\ seckiner@gantep.edu.tr, alikoc_1960@hotmail.com
}

Received/Gelis Tarihi: 06.09.2018

Revision/Düzeltme Tarihi: 09.10.2019

doi: $10.5505 /$ pajes. 2019.36845

Accepted/Kabul Tarihi: 11.10.2019 Review Article/Derleme Makalesi

\begin{abstract}
Healthcare facilities are one of the main buildings that have great energy consumption. This situation reveals the need for good energy planning and management based on the principles of energy efficiency as well as cost-effectiveness for these facilities. In this context, a literature review, between 2006 and 2018, on energy applications realized for healthcare facilities, such as energy planning, energy management, energy efficiency, selection of alternative energy technologies, using of different energy sources, energy renovation/refurbishment activities have been executed. A Systematic Literature Review (SLR) method was used, where research questions and searching stages were defined. This review study has been conducted on energy and healthcare relevant keywords in the Scopus database. After a thorough analysis of the papers retrieved from the Scopus database, a total of 176 primary articles has been categorized according to their relations with energy efficiency, energy planning, and energy management. In each category, major research issues, findings, and important aspects have been analyzed and reported. With this analyzing, developments in the existing literature have been put forth and potential areas for future research have been suggested. Findings pointed out that energy-related studies for healthcare facilities are between trending topics. For ensuring minimum cost and maximum utility for energy, the articles using the solution methods of operations research and engineering economics regarding alternative energy applications are especially popular. As a solution method for energy problems, Mixed Integer Linear Programming (MILP) is widely used in 20 studies. On the other hand, cogeneration and trigeneration applications, which minimize energy costs and waste energy and are very suitable for large buildings, are the most frequently studied alternative energy applications with 83 articles.
\end{abstract}

Keywords: Energy, Energy management, Healthcare, Hospital.

\section{Öz}

Sağlık tesisleri, büyük bir enerji tüketimine sahip ana binalardan biridir. Bu durum, enerji verimliliği ilkelerine ve bu tesisler için maliyet etkinliğine dayalı iyi bir enerji planlaması ve yönetimine duyulan ihtiyacı ortaya koymaktadır. Bu bağlamda, 2006 ve 2018 yılları arasında enerji planlaması, enerji yönetimi, enerji verimliliği, alternatif enerji teknolojilerinin seçimi, farklı enerji kaynaklarının kullanılması, enerji yenileme/yenileme çalışmaları gibi sağlık kurumları için gerçekleștirilen enerji çalıșmalarına ilişkin literatür taraması gerçekleștirilmiștir. Araștırma sorularının ve arama așamalarının tanımlandığı bir sistematik literatür taraması methodu kullanılmıştır. Bu literatür çalıșması, Scopus veritabanında enerji ve sağlık ile ilgili anahtar kelimeler üzerine yapılmıştır. Scopus veritabanından elde edilen verilerin analizinden sonra, toplam 176 öncellikli çalıșma enerji verimliliği, enerji planlaması ve enerji yönetimi ile ilişkilerine göre sınıflandırılmıștır. Her kategoride, önemli araștırma konuları, bulgular ve mühim görülen yönler analiz edilmiș ve raporlanmıștır. Bu analiz ile mevcut literatürdeki gelişmeler ortaya konmuş ve gelecekteki araștırmalar için potansiyel alanlar önerilmiștir. Elde edilen sonuçlar sağlık tesisleri için enerji ile ilgili çalışmaların trend konular arasında olduğunu göstermektedir. Enerji için minimum maliyet ve maksimum fayda sağlamak amacıyla, alternatif enerji uygulamalarına yönelik olarak yöneylem araştırması ve mühendislik ekonomisinin çözüm yöntemlerini kullanan makalelerin özellikle ön planda olduğu belirlenmiştir. Enerji problemleri için çözüm yöntemi olarak, Karma Tamsayılı Doğrusal Programlamanın 20 makale ile en çok kullanılan yöntem olduğu görülmektedir. Öte yandan, enerji maliyetlerini ve atık enerjiyi mimimize eden ve büyük binalar için oldukça uygun olan kojenerasyon ve trijenerasyon uygulamalarının 83 makale ile üzerinde en çok çalışılan alternatif enerji uygulamaları olduğu görülmektedir.

Anahtar kelimeler: Enerji, Enerji yönetimi, Sağlık hizmeti, Hastane.

\section{Introduction}

The energy issue is very important and an indispensable element of today. The factors such as limited resources, excessive and growing consumption, high costs make it mandatory to have an energy management perspective and using energy efficiently. In this context, efficient and planned energy management is widely accepted as an emerging factor for the future life of humanity, which requires not only technical innovation and alternative energy resources but also the awareness of all consumers about the depletion of resources and efficient use of energy.
Energy use intensity and energy diversity are important indicators for the level of development of societies in today's world. Furthermore, energy is one of the primary components in economical development and there is a certain relation between the intensity of using and availability of energy and the growth of a nation. On the other hand, the development of the healthcare sector is another important indicator for societies from the point of showing their place in the developed world. Technology usage in the healthcare sector is becoming indispensable, so the dependence on energy is more vital today. For instance, the technological developments and usage status are intensive in medical devices, which are used in the critical units such as operating rooms, $\mathrm{x}$-ray and imaging units,

${ }^{*}$ Corresponding author/Yazışılan Yazar 
intensive care units that have a direct impact on the lives of patients. Especially these units in running hospitals require an uninterrupted supply of energy every day because medical technology that consumes immense amounts of energy is at work around the clock. Another technological development for healthcare facilities is building-relevant technologies and systems which are HVAC systems, combined energy units, motors, lighting systems, video surveillance, intrusion and fire detection systems, alarm and evacuation. They secure comfort, hygiene and the safety of patients and staff while allowing for streamlined operation and making life easier.

Especially, as great energy consumers, hospitals, hotels, large sports centers, and other buildings are responsible for $40 \%$ of energy consumption and $36 \%$ of $\mathrm{CO}_{2}$ emissions in the $\mathrm{EU}$ [1]. Healthcare facilities, in particular, large hospitals, have an important place in the building types in terms of energy consumption. Hospitals have great energy consumption because of long work durations and intensive people circulation who are employees, patients, and visitors. These buildings are 24hour/7day open to operation and they are occupied by sophisticated HVAC systems that led the temperatures and airflow. Besides that, many energy-required units and activities are actualized in these buildings: such as washeteria, medicinal and lab equipment use, imaging unit, sterilization, computer and other office equipment use, food service, and refrigeration. For example, a typical 200,000square-foot $\left(\mathrm{ft}^{2}\right), 50$-bed hospital in the U.S. annually spends $\$ 680,000$ - or roughly $\$ 13,611$ per bed-on electricity and natural gas [2]. Healthcare professionals are looking for new and cost-effective energy solutions and safe ways for energyproviding to balance great costs caused by growing consumption and rising energy prices. Because of all these reasons, the main topics such as energy planning, energy management, energy efficiency, the implementation of alternative energy technologies and energy sources, energy audit programs, energy renovation, and refurbishment activities in healthcare facilities require further analyzing.

When energy-relevant studies of healthcare facilities are examined, it seems clear that the use of alternative energy technologies and sources were the most studied subject. Cogeneration applications producing heat and electric power using generally natural gas are in the first rank in this subject. Cogeneration is one of the preferred alternative energy production methods for hospitals. A combined heat and power (CHP) system could produce both electricity and heat simultaneously [3]. Combined heat and power systems are generally accepted as one of the most effective solutions to accomplish the increasing requirements in primary energy consumption reduction and greenhouse emissions reduction [4]. The implementation of the cogeneration system incorporates lots of parameters such as energy demand under uncertainty, the return on investment, define optimum operation strategy, appropriate equipment selection, amount and type of energy generation which reveals the necessity of an optimal viewpoint.

Similarly, the other alternative technology is trigeneration which is obtained by adding an absorption chiller or cooling unit to the cogeneration plant. With the connection of the absorption chiller and cogeneration system, the system starts to have the ability to generate three energy formation (electricity, cooling, and heating) from a single source simultaneously. Healthcare facilities have buildings that are consuming a great amount of energy with long operating hours, thus they are appropriate to set up a CHP or CHCP plant. Some facilities, besides electricity usage for office requirements and cooling equipment, a thermal energy source is used for general heating or medical services, such as sterilization, laundry, and kitchen heating [5]. The main problems in these applications are determining capacity and designing parameters since high investment costs and correspondingly increasing of a breakeven point are directly related [5]-[8]. For example, In their study, Guo L. et al. [6], proposed a two-stage optimal planning and design method whose optimum objective is to both minimize the total net present cost and carbon dioxide emission in life circle using multi-objective genetic algorithm while designing trigeneration plant for the hospital. Another issue is the use of CHP or CHCP systems is determining optimum operation strategy for increase system performance by taking into consideration important indicators such as hourly hospital energy demands, peak load, tariffs [5],[9],[10]. In the healthcare facilities, trigeneration and cogeneration systems are sometimes operated based on renewable energy resources such as photovoltaic solar panels, biogas, solar oxide fuel cell which is modeled and optimized for the trigeneration hybrid system fed by biogas produced from hospital waste [11].

To reduce energy consumption, healthcare facilities sometimes look for ways to improve the current situation of buildings instead of using alternative energy technologies and sources. Renovation/Refurbishment activities, which are building envelope and insulation, insulation of pipes, window shading, insulated roof, insulation of hot water tanks and boilers, thermostatic radiator valves, boiler replacement, replace old electromagnetic ballasts with electronic ones, etc. [12], often are applied to save energy in healthcare facilities. These activities mean a reduction in future energy bills and a better indoor climate and greater comfort. Sometimes these activities are applied within the framework of an energy audit program or energy maintenance contract, and sometimes these are applied independently. It was signed a contract with an Energy Service Company (ESCO) partnership for energy efficiency in Ottawa Hospital (TOH) within the framework of began its energy reduction program [13]. The Advanced Energy Design Guide for Small Hospitals and Healthcare Facilities (AEDG-SHC) provides user-friendly support and advice for building design, construction, and owner communities to achieve energy savings [14].

However, in some studies [15],[16], it was carried out energy data analysis regarding the hospital's existing situation to ensure a database or framework for future energy efficiency activities. Martini et al. [15], tackled the energy behavior of health facilities, with a knowledge base of the EnergyProductive Building Module which provides evaluating the interactions among various physical spaces, building envelope, infrastructure, and equipment related to energy consumption. Similarly, Congradac et al. [16], studied on practice and approval of the energy consumption tool.

In this paper, a systematic literature review has been carried out to define and critically survey the literature on the healthcare facilities energy subjects from 2006 to 2018 from the point of energy planning, energy management, energy efficiency, alternative energy sources, energy renovation and refurbishment activities for healthcare facilities.

Energy efficiency surveys in health care have become an important research aspect after 2005 with the increasing use of renewable energies. The studies between 2006-2018 are an 
important period in terms of shedding light on past and future studies. However, the tendency of such studies should be investigated on a sectoral basis at certain intervals

As shown in Table 1, the study was organized based on specified stages.

Table 1. Figure list.

\begin{tabular}{|c|c|}
\hline \multicolumn{2}{|r|}{ Hierarchical Stages in The Study } \\
\hline Stages & Main Issues \\
\hline Stage 1 & $\begin{array}{c}\text { Reviewing All Articles Between 2006-2018 Based on } \\
\text { Defined Search Criteria }\end{array}$ \\
\hline Stage 2 & Retrieving Related Articles \\
\hline Stage 3 & $\begin{array}{l}\text { Analyzing Articles and Obtaining Inferential General } \\
\text { Information About Articles }\end{array}$ \\
\hline Stage 4 & $\begin{array}{l}\text { Analyzing Retrieved Articles From The Point Of Using } \\
\text { the Methods and Tools of Industrial } \\
\text { Engineering/Operational Research }\end{array}$ \\
\hline Stage 5 & $\begin{array}{c}\text { Analyzing Retrieved Articles From The Point Of Using } \\
\text { the Alternative Energy Technologies/Sources } \\
\text { Analyzing Retrieved Articles From The Point Of }\end{array}$ \\
\hline Stage 6 & $\begin{array}{l}\text { Renovation/Refurbishment Activities for Energy } \\
\text { Efficiency For Healthcare Facilities }\end{array}$ \\
\hline Stage 7 & $\begin{array}{l}\text { Studying the Energy Types which are main energy } \\
\text { outputs such as electricity, heating, hot water and } \\
\text { cooling }\end{array}$ \\
\hline
\end{tabular}

\section{Research methodology}

An SLR procedure was applied to identify and select a relevant and representative set of literature to answer the research question and its sub-questions [17]. In this paper, we present the design and the organizing of a systematic literature review that we performed to assess the current state of research on healthcare facilities' energy efficiency/planning/management in the time interval 2006-2018. The adopted research methodology consists of five parts that are specifying the research questions, determining goal and strategy, defining inclusion and exclusion criteria, starting the searching process, analyzing and inferring useful knowledge.

In this review study, we first have to define our research questions that are expressive and important for practitioners as well as researchers. Our analysis and inference from the relevant articles are based on the research questions. Therefore, it is very important to answer research questions correctly that will influence current practice and extend the body of knowledge. Our Research Questions (RQ) are proposed as follow;

- Which approaches are proposed to solve, model or specify energy problems in healthcare facilities?

- Which alternative technologies and sources have been used in healthcare facilities?

- Which measures have been taken for energy saving in healthcare buildings?

- What kind of energy and which extent is used?

The basic objective of this study is to identify all articles, which are directly relevant to the healthcare facilities' energy efficiency/planning/management subject, which was published in peer-reviewed journals between 2006 and 2018 years and evaluating these articles based on their contents. To achieve this goal, two main headlines, which are "Energy" and "Healthcare, Medicine", have been get reference in the specified database. The searching has been looked for within the titles, abstracts, and keywords of all articles of relevant peer- reviewed journals by the keywords specified in Table2. On the other hand, if insufficient information is available in titles and abstracts, a full-text review is also realized as a general principle.

Table 2. List of search keywords.

\begin{tabular}{|c|c|c|}
\hline \multicolumn{3}{|c|}{ List of Search Keywords } \\
\hline \multicolumn{2}{|c|}{ In Energy Journals } & $\begin{array}{c}\text { In } \\
\text { Healthcare } \\
\text { or Medicine }\end{array}$ \\
\hline Hospital & Healthcare & Energy \\
\hline Hospital & Healthcare Center & Energy \\
\hline Hospital Building & Healthcare Building & Electricity \\
\hline Hospital Facility & Healthcare Clinic & Heating \\
\hline Hospital Center & Healthcare Establishment & Cooling \\
\hline Hospital Unit & Healthcare Unit & Exergy \\
\hline Hospital Room & Healthcare Sector & \\
\hline & Healthcare Company & \\
\hline
\end{tabular}

The first inclusion and exclusion criterion for the articles, which were published in relevant peer-reviewed journals and included aforementioned keywords in their titles and abstracts, are determining relevance them with the purpose and title of the study. This means that an article includes not only "hospital/healthcare or energy" keywords in its title and abstract, but also it has to be related to the aim of the study and so only articles explicitly discussing the hospital energy efficiency/planning/management has been chosen. On the other hand, the second criterion is that one of the determined duplicate articles is removed from the detailed table. As the third one criterion, the retrieved articles related to the topic published in the different publications (journals, conferences, etc.), which have cited our predetermined relevant articles, have been taken into consideration additionally.

After careful and planned preparation, the searching process has been started under the aforementioned rules in the Scopus database with identified keywords. The retrieved articles were saved in a detailed table together with their properties such as journal name, article name, publication year, citations, first author affiliation, etc. as shown in Table 3 . All saved articles were reviewed based on the title and abstract to evaluate their relevance for inclusion in the final classification. Furthermore, the studies, which were cited relevant to each article, were examined to minimize the number of overlooked relevant articles. When an article not on the detailed table is determined, it will be added to the table and it will be subjected to the same process. As mentioned above, the articles related to the topic published in the different publications (journals, conferences, etc.), which cite our predetermined relevant articles, have been taken into consideration additionally.

Eventually, the determined relevant articles were read one by one as abstract or full-text for analyzing. Each article was analyzed following the properties identified in Table 4 below. With this analyzing, developments in the existing literature have been put forth and potential areas for future research have been suggested. Detailed analysis and its results will be discussed in Section 3. 
Table 3. Sample data for relevant article.

\begin{tabular}{|c|c|c|c|c|c|c|c|c|c|c|c|}
\hline $\begin{array}{c}\text { Referen } \\
\text { ce } \\
\text { Number }\end{array}$ & Doi & $\begin{array}{l}\text { Journal } \\
\text { Name }\end{array}$ & Article Name & $\begin{array}{l}\text { Dijital } \\
\text { Library }\end{array}$ & $\begin{array}{c}\text { Number } \\
\text { of } \\
\text { Citations }\end{array}$ & Year & $\begin{array}{c}\text { First } \\
\text { Author } \\
\text { Affiliation }\end{array}$ & Country & Department & $\begin{array}{c}\text { Public } \\
\text { Participation }\end{array}$ & $\begin{array}{c}\text { The number of articles } \\
\text { related to our main } \\
\text { topic in Citations }\end{array}$ \\
\hline 44 & $\begin{array}{l}10.10 \\
16 / j . a \\
\text { pener } \\
\text { gy.201 } \\
6.04 .0 \\
78\end{array}$ & $\begin{array}{l}\text { Applied } \\
\text { Energy }\end{array}$ & $\begin{array}{l}\text { Multi-stage and multi- } \\
\text { objective optimization for } \\
\text { energy retrofitting a } \\
\text { developed hospital reference } \\
\text { building: A new approach to } \\
\text { assess cost-optimality }\end{array}$ & $\underline{\text { Scopus }}$ & 45 & 2016 & $\begin{array}{l}\text { Fabrizio } \\
\text { Ascione }\end{array}$ & Italy & $\begin{array}{c}\text { University } \\
\text { of Naples } \\
\text { Federico II, } \\
\text { Piazzale } \\
\text { Tecchio }\end{array}$ & $\begin{array}{c}\text { Public } \\
\text { Education }\end{array}$ & 5 \\
\hline
\end{tabular}

Table 4. Sample detailed data table of relevant articles.

\begin{tabular}{|c|c|c|c|c|c|c|c|c|c|}
\hline $\begin{array}{l}\text { Reference } \\
\text { Number }\end{array}$ & $\begin{array}{l}\text { Journal } \\
\text { Name }\end{array}$ & Article Name & $\begin{array}{l}\text { Use of Other } \\
\text { Engineering Solution } \\
\text { Methods? }\end{array}$ & $\begin{array}{l}\text { Use of Industrial } \\
\text { Engineering or } \\
\text { Operation } \\
\text { Research (OR) } \\
\text { Solution Methods } \\
\text { ? }\end{array}$ & $\begin{array}{l}\text { Use of Alternative } \\
\text { Novel Energy } \\
\text { Technology or } \\
\text { Novel Energy } \\
\text { Source } \\
\text { (Cogeneration, } \\
\text { trigeneration, } \\
\text { photovoltaic etc.) }\end{array}$ & $\begin{array}{l}\text { Which Energy } \\
\text { Form? (Cooling, } \\
\text { Heating, Electricity, } \\
\text { Hot Water) }\end{array}$ & $\begin{array}{l}\text { System Simulation } \\
\text { Program (Building } \\
\text { Simulation, Renewable } \\
\text { Energy Simulation, CHP } \\
\text { and CHCP Simulation) }\end{array}$ & $\begin{array}{l}\text { Interest with } \\
\text { topic }\end{array}$ & The Aim Of Article \\
\hline 44 & $\begin{array}{c}\text { Applied } \\
\text { Energy }\end{array}$ & $\begin{array}{l}\text { Multi-stage and multi- } \\
\text { objective optimization for } \\
\text { energy retrofitting a } \\
\text { developed hospital reference } \\
\text { building: A new approach to } \\
\text { assess cost-optimality }\end{array}$ & $\begin{array}{c}\text { Engineering } \\
\text { Economic Analysis } \\
\text { (Cost-0ptimal } \\
\text { Analysis) }\end{array}$ & $\begin{array}{l}\text { Multi-stage and } \\
\text { multi-objective } \\
\text { (Pareto) } \\
\text { Optimization, } \\
\text { Multi-objective } \\
\text { Genetic } \\
\text { Algorithm, } \\
\text { Cost-Optimal } \\
\text { Analysis }\end{array}$ & $\begin{array}{c}\text { Trigenration } \\
\text { System (CHCP } \\
\text { System), Solar } \\
\text { photovoltaic (PV) } \\
\text { panels, Solar } \\
\text { thermal collectors }\end{array}$ & $\begin{array}{l}\text { Heating, Cooling, } \\
\text { Electricity, Hot } \\
\text { Water }\end{array}$ & Yes/EnergyPlus & $\begin{array}{c}\text { Energy } \\
\text { Efficiency } \\
\text { (Renovation/ } \\
\text { Refurbishment) } \\
\text {, Energy } \\
\text { Efficiency } \\
\text { (Use New } \\
\text { Technology) }\end{array}$ & $\begin{array}{l}\text { The objective of this study is } \\
\text { addressing these knowledge gaps } \\
\text { by proposing a novel methodology } \\
\text { that is, then, employed to identify the } \\
\text { cost-optimal energy retrofit of a } \\
\text { developed Italian hospital } \\
\text { RB, by considering all levers affecting } \\
\text { energy performance. }\end{array}$ \\
\hline
\end{tabular}

\subsection{Database profile}

In this study, Scopus has been taken into consideration as a reference database. Scopus is the largest abstract and citation database of peer-reviewed literature: scientific journals, books and conference proceedings [18]. The search for journals and articles in Scopus consists of the following steps as shown in Figure 1;

- Browse Sources,

- Select Subject Area (For this study "Energy" and "Medicine/Healthcare") and select source type as journals,

- Select a relevant journal and open webpage of the journal (relevant total 54 peer review journals),

- $\quad$ Select year and search articles according to keywords.

\subsection{Publication Profile}

As stated above, the Scopus database was used to investigate articles that were published in peer-reviewed journals between 2006 and 2018 and identified energy applications/ studies for healthcare facilities. The process of determining relevant publications and retrieving articles, as shown in Figure 2, regarding our subject comprises two stages. In the main stage, the scope of research has covered 54 peer-reviewed journals that have been divided into two main categories that are "energy" and "healthcare or medicine". After searching in peerreviewed journals through the specified database with the use of our keywords, we have made the primary search and identified 305 articles from the automatic search stage in the approximately 100.000 articles. These 305 studies were checked against the research questions and the criteria of inclusion and exclusion (exclusion for title, abstracts, and keywords) and non-useful results were eliminated in this step. At the next step, some articles were excluded that were unrelated to our subject based on the review of their titles, abstracts, and keywords. In the case of uncertainty, the checking process was proceeding in the next step. For this purpose, in the third step of this stage, the selection criteria were applied considering the full text (exclusion based on the full text), consequently, 3 studies also have been excluded, since these have been evaluated as duplicates and removed from the detailed table by reading of their text. These duplicate ones haven't been taken into consideration but they were also shown in the references.

With the elimination of inappropriate studies, we were prepared for the second stage. In the second stage, after all of the 156 remaining articles were screened, the additional 46 papers cited our main papers based on the aforementioned rules were listed with their titles and abstracts. Subsequently, these 46 papers were added to the detailed table and we then generated the pre-final set of primary articles. After the full text revising of these additional articles based on the resource questions and inclusion and exclusion criteria, 26 papers were removed. The remaining 20 articles citing to our main relevant articles have been taken into consideration that they were evaluated as appropriate for research questions, even though they have been published in different publications such as other journals, conferences, congress. Finally, 176 studies have identified as primary studies and formed the basis for the next steps in our review study as stated in the references. The distribution of these articles by years is shown by Figure 3 that is indicated a tendency to rise. 


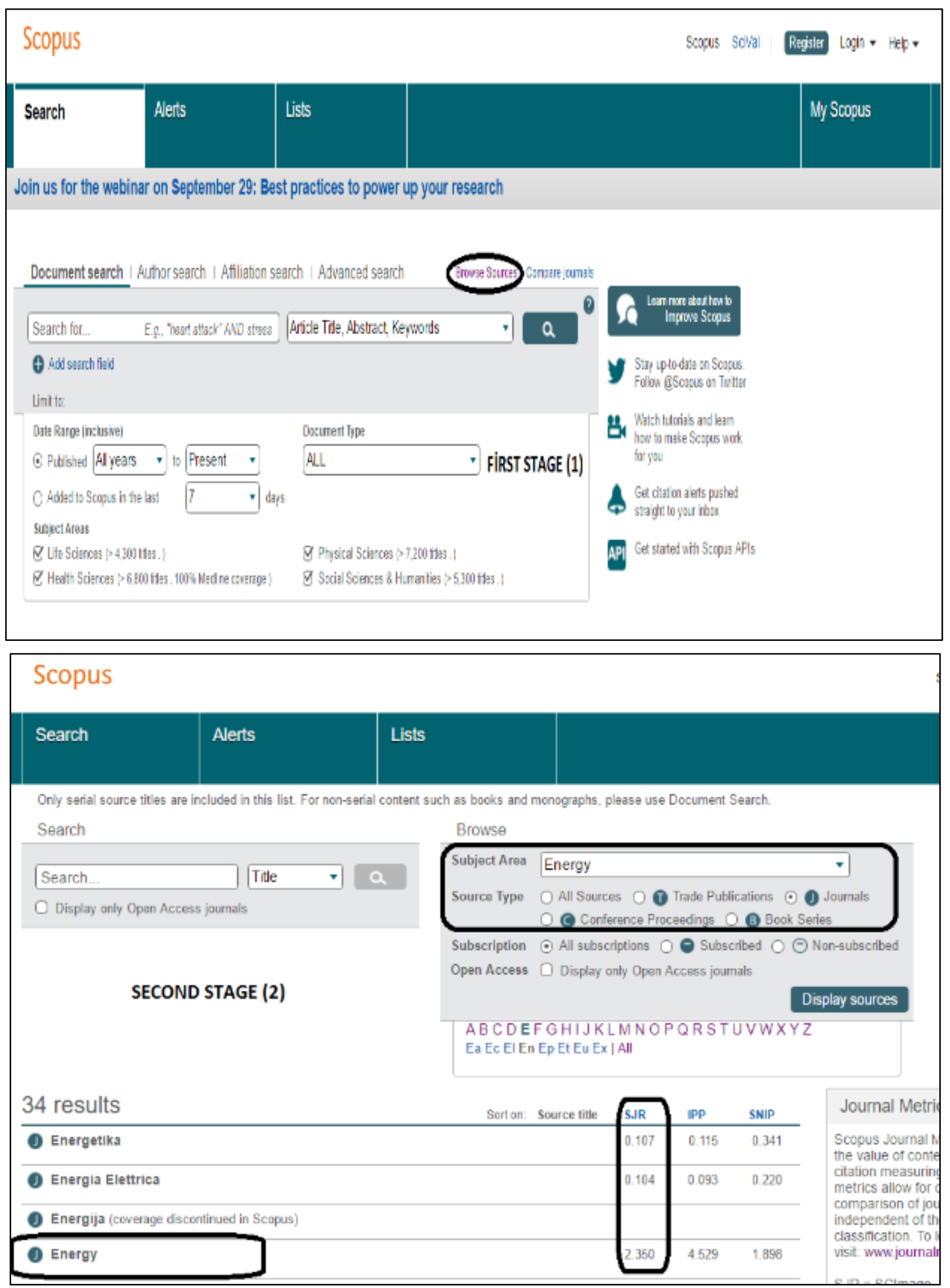

Figure 1. Search steps in Scopus. 


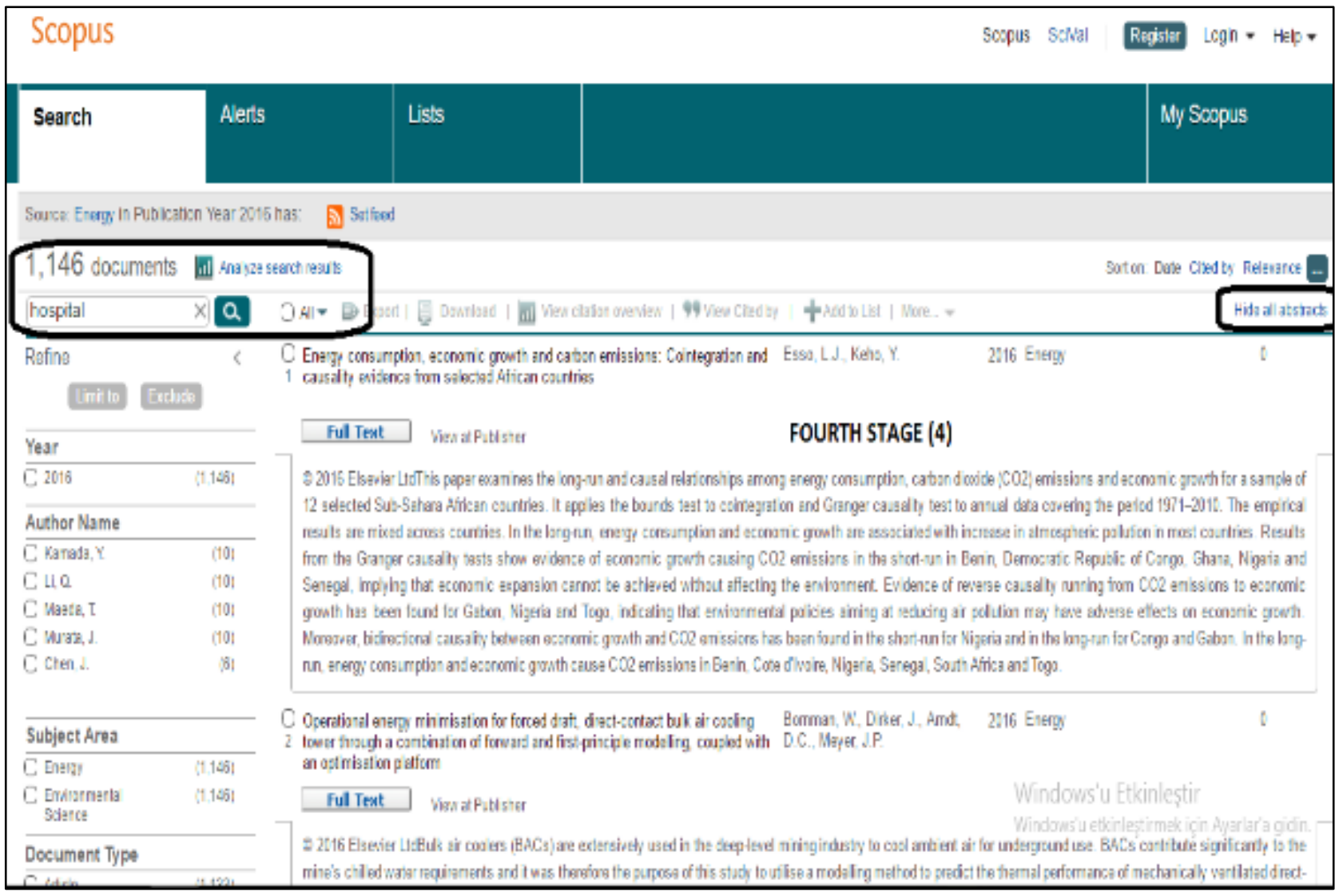

Scopus

Scopus 5

\begin{tabular}{|l|l|}
\hline Search & Alerts \\
\hline
\end{tabular}

\section{Lists}

Joumal Homepage

\begin{tabular}{|c|c|}
\hline Energy & \\
\hline $\begin{array}{r}\text { Subject Area: } \\
\text { Publisher: } \\
\text { ISSN: } \\
\text { E-ISSN: } \\
\text { Scopus Coverage Years: }\end{array}$ & $\begin{array}{l}\text { Energy } \\
\text { Polution } \\
\text { Elsever Limiled } \\
0380-5442 \\
1873.6785 \\
\text { from } 1976 \text { to Present }\end{array}$ \\
\hline
\end{tabular}

Joumal Metrics

Scopus Joumal Metrics offer the value of context with their citation measuring tools. The metrics below allow far drect comparison of journals, independent of their subject classification. To leam more, visit www. jounalmetrics.com

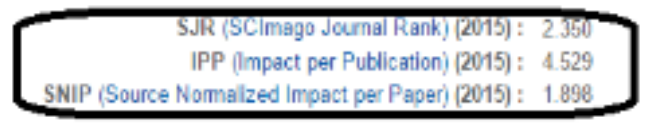

[- Compare with other joumals

Documents available from

(1.) Articles in press ?
THIRD STAGE (3)

Follow this source

tecelve emalls when ne: cucuments are avallable in Scopus

SJR, IPP, and SNIP

S.JR = SClmago Joumal Rerk is weighted by bhe prestige of a joumal. Subject field, qualty and reputation of the journal have a drect effect on the value of a citation. SJR also normalizes for differances in citation behaviar between subject fields

IPP = Impact per Putlication (IPP) measures the ratio of citations per article publlished in the lournal.

SNIP = Source Nomalized Impact per Paper measures contextual citation impact by weighting cilations based on the total number of cilations in a subject field.

\section{Open Access Journals}

Journals covered by Scopus are indicate Open Access if the joumal is isted in the of Cpen Access Journals ( DOAJ) and $/ 0$ Drectory of Open Access Scholarty Resc ROAD)

Figure 1. Search steps in Scopus. 


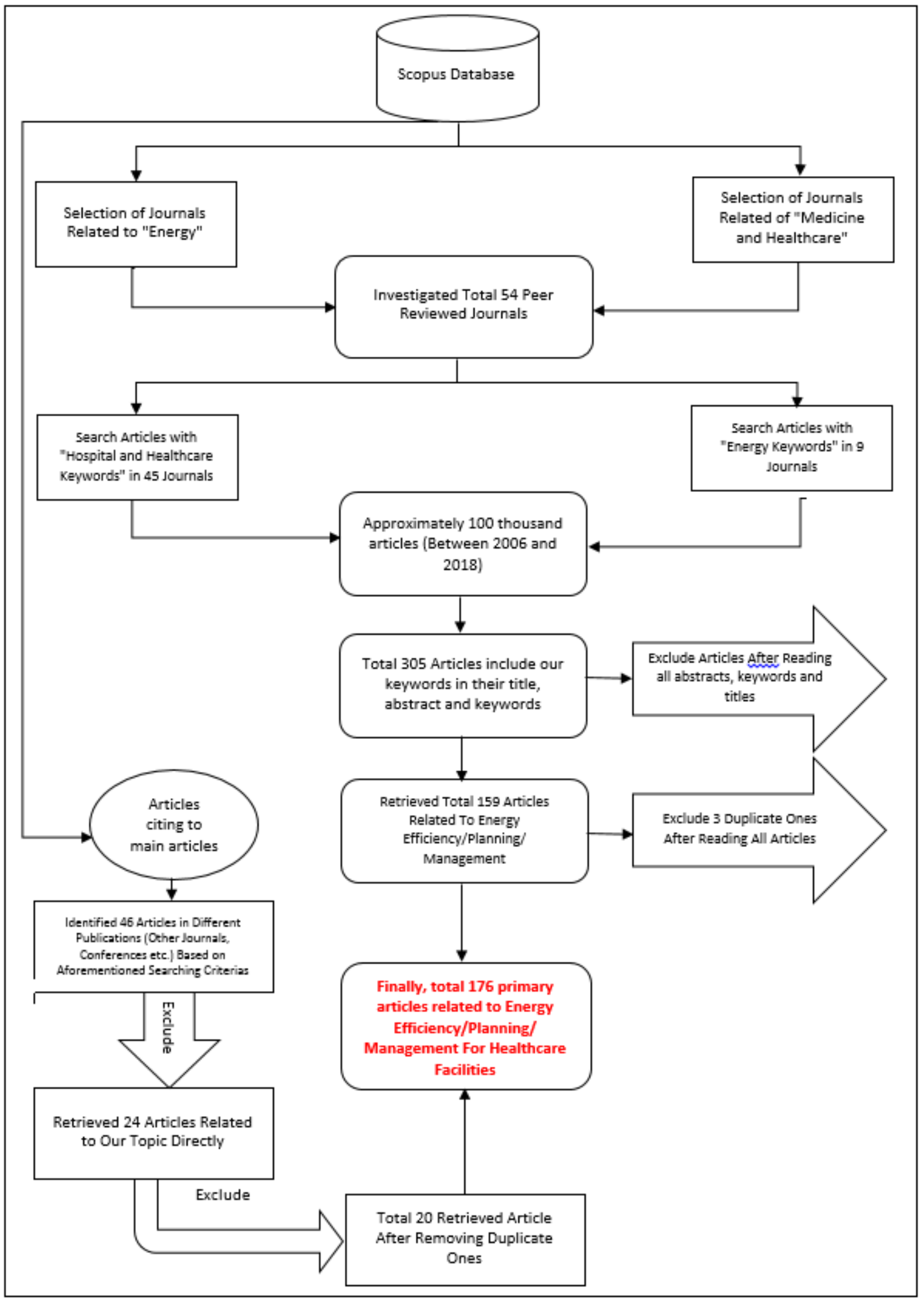

Figure 2. The flow chart of searching. 


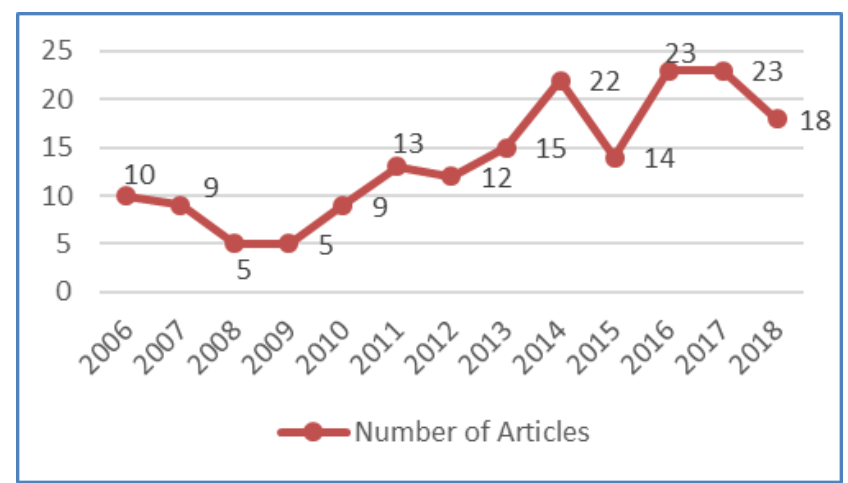

Figure 3. Distribution of relevant articles by years.

Some of the journals in the main stage under the "Energy" head, which includes 45 journals and 152 relevant articles in total, are Energy and Buildings, Energy, Applied Energy, Applied Thermal Engineering, Energy Conversion and Management, Energy Policy, Energy Efficiency. On the other side, some of the journals that were reviewed related to healthcare are the Journal of Healthcare Engineering, Health Environments Research and Design Journal, Health Services Research under the "Healthcare, Medicine" head, which includes 9 journals and 7 relevant articles. It can be seen from the list of journals above that research for healthcare facilities' energy efficiency/planning/management is involving management, technical and healthcare dimensions. The top 10 journals which contain maximum relevant articles (approximately \%71 of all relevant articles) are indicated in Figure 4 as below.

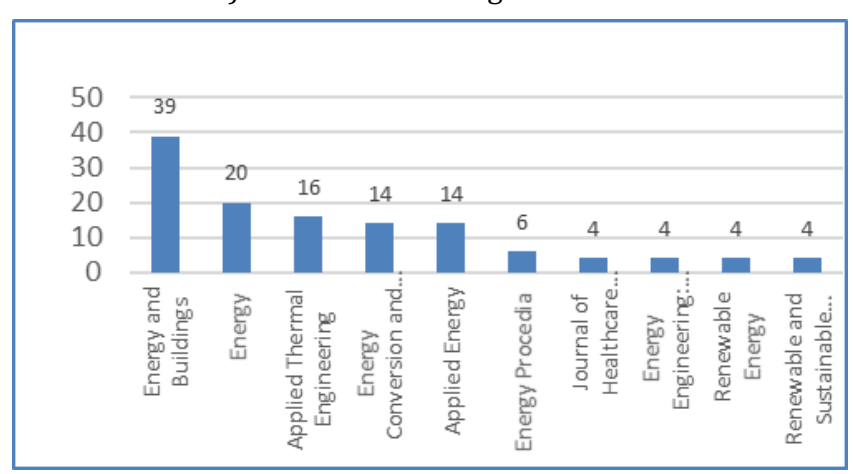

Figure 4. Distribution of relevant articles by journals.

\section{Analysis and results}

Before moving on to basic analysis titles, we think it has to be given some important inferential information about relevant articles. As a result of the analysis of healthcare facilities were carried out relevant studies, six types of healthcare facilities have been defined as shown in Figure 5.

Most studies have been realized in "500-beds and over" hospitals, whereas the minimum number of studies have been actualized in other medical units (laboratories etc.). In our opinion, the increase in the number of studies depending on the size of healthcare facilities is associated with the increase of the amount of consumed energy and variety of energy sources that could be studied in lots of situations. In this context, Figure 6 indicates that the distribution of studies that are involved the most preferred alternative energy sources such as trigeneration, cogeneration and photovoltaic based on healthcare facility capacity and type.

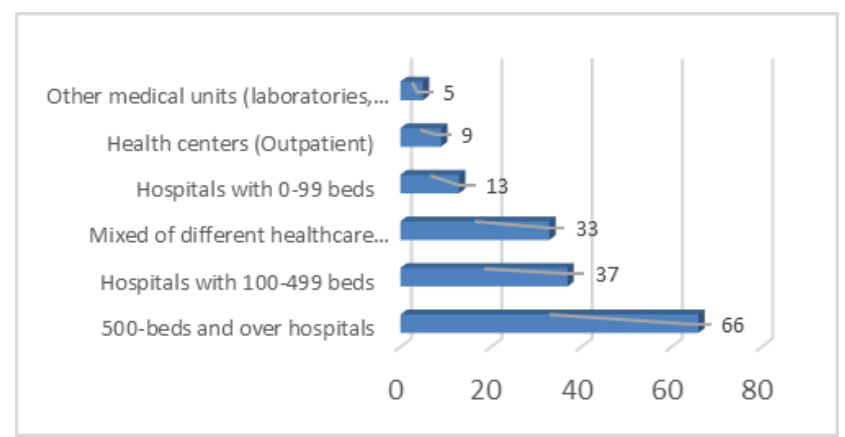

Figure 5. The Number of articles per healthcare facility type.

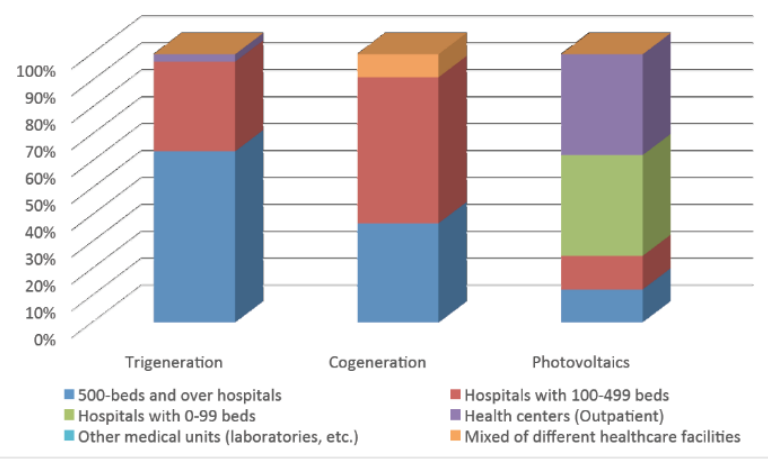

Figure 6. The Distribution of some alternative energy technologies and sources based on healthcare facility type.

As a conclusion, although the studies regarding alternative energy technologies like trigeneration have been carried out for big hospitals such as 500-beds and over hospitals, the studies about alternative energy sources like photovoltaic have generally concentrated on small healthcare facilities such as health centers (outpatient) because of having long payback period and higher break-event point Figure 7 shows that the number of relevant articles per country between 2006 and 2018 where Italy has the maximum relevant studies with 35 articles followed by Spain with 23 articles. In total, Europe countries have the biggest margin with approximately $48 \%$ percentage.

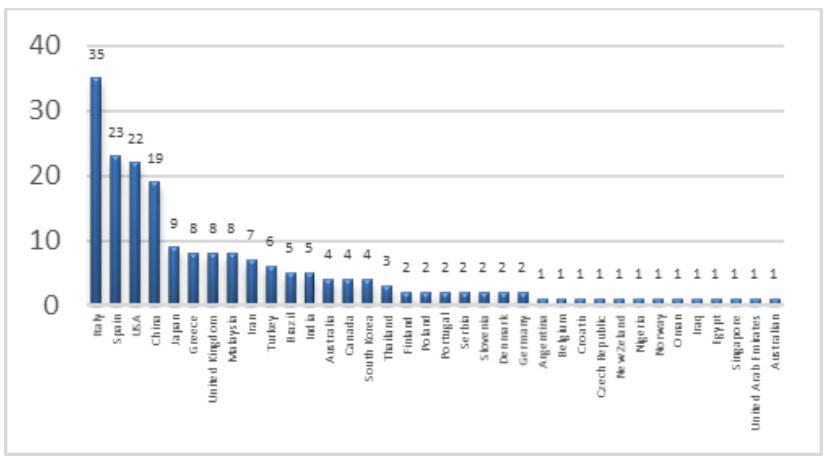

Figure 7. Distribution of relevant articles by countries.

We have divided basic analysis titles into four groups to demonstrate the solution methodologies for energy planning problems, the usage of alternative energy technologies and sources, energy efficiency activities and energy forms used in healthcare facilities. The retrieved studies were classified based on various parameters as mentioned in Table 4, which ensures to analyze all studies and to obtain meaningful results. 


\subsection{The Use of IE and OR methodologies and results}

Industrial engineering (IE) and especially operations research (OR) tools and methods are very useful and effective to solve and to manage an array of business and organizational problems. The basic approach behind OR methods, which are generally implemented under uncertainty, is to cooperate with customers to plan and develop operations, make better decisions and solve problems. OR methods have been successfully used in a variety of applications involving energy, transportation, production, the environment and in several engineering and management problems. On the other hand, energy management and planning has become an essential part of business strategy in a global economy. It has been understood that energy management is one of the key factors in lowering costs and driving efficiency and innovation throughout an organization. In a general manner, the energy management process requires a continuous improvement perspective involving visualizing real-time energy consumption, measurement, analysis, planning, and implementation of programs to reduce consumption and cost.

Energy planning problems with multiple objectives such as minimum energy cost, maximum system utility, minimum $\mathrm{CO}_{2}$ emission, and minimum energy consumption are complex including multi decision-makers, multi-energy sources and multi-parameter, so they should be solved by appropriate and effective solution methods. The solution methods of OR are gaining ever higher importance in the energy sector e.g. optimization problems have an important position in energy management and planning. The success of these methods has been proved in many studies for several years in energy planning and scheduling problems.

The different applications such as to minimize application cost of alternative energy technology, energy demand forecasting under uncertainty, energy scheduling for different units/ buildings are basic areas for these methods in which can be used in healthcare energy management and planning. All retrieved relevant articles have been classified and analyzed in terms of using IE and OR methods and tools. Although some methods and tools have been used in other disciplines like statistics, economy, etc., we have evaluated them in terms of industrial engineering and operations research. Different solution tools and methods, considered as related to IE and OR, have used in total 71 relevant articles. On the other hand, when we look at authors of these retrieved articles, 22 articles were published by departments of Industrial Engineering and Operations Research (or similar departments). As can be seen from Figure 8, the use of such methods is increasing by the years in energy-related studies for healthcare facilities. Furthermore, Figure 9 shows that the most used several methods were used in relevant articles.

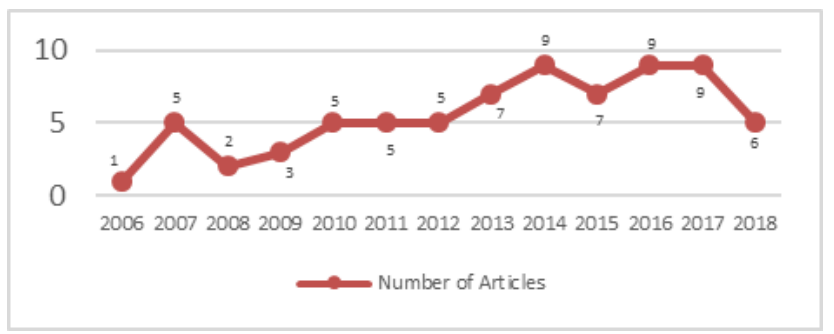

Figure 8. IE and OR methods in relevant articles by years.

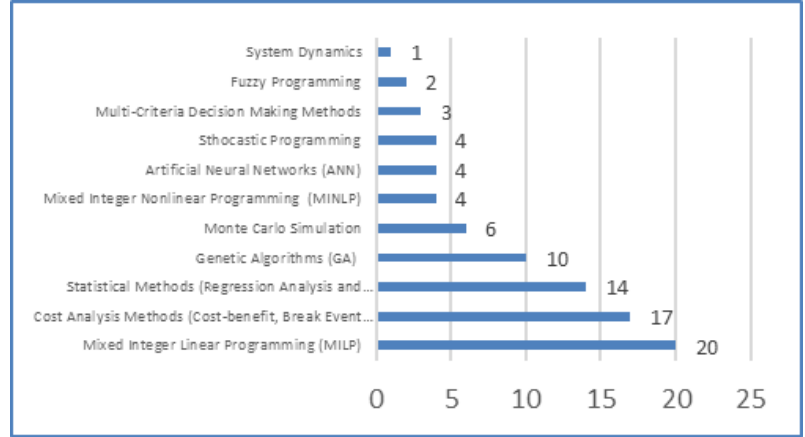

Figure 9. The most used IE and OR methods in relevant articles.

When these methods are analyzed as per the studies, Figure 9 shows that Mixed Integer Linear Programming (MILP) is the most commonly used method in this manner. For more than 40 years, Mathematical Programming is a widespread tool for energy planning with aiming the cost minimization subject to demand and user satisfaction [19]. This method was sometimes used alone to solve energy problems [20],[21]-25 and [27]-[29], whereas it was sometimes used together with auxiliary or supporting methods such as fuzzy programming [30], monte carlo simulation [19], cost-benefit analysis [31], pareto optimization [32], robust optimization [33],[34], multiobjective Genetic Algorithm (GA) [33] and stochastic programming [35]. As can be seen from the studies that used this method, it has been used to obtain an optimum solution for the problems, which are occurred with the application of new energy sources, such as optimum operating cost and strategy, evaluating equipment performance. This method was not only used based on a single objective, which is generally minimizing total annual cost [20],[19]-[24],[31],[34],[36]-[38] and [39], but also it was used based on multi-objective such as ton minimize the costs and to maximize demand satisfaction [30], minimizing the total annual carbon dioxide emissions/ minimizing the global environmental impact/minimizing the costs [25,32], total cost of system and CO2 emission [33], the trade-off between the economic and environmental aspects [27].

Genetic algorithm (GA) as another popular method has lots of advantages in using energy planning problems that it manages the formulated problem as a black box, caring only for inputs and outputs, without needing any other auxiliary information like derivatives or continuity properties of the objective function [40]. Although this method was generally used to solve multi-objective problems [4],[40],[41] and [42]-[44], it was used to solve for some single-objective problems too [11],[45]. For example, Guo L. et al. [6], presented a two-stage optimal planning and design method, the first stage of which is a multiobjective genetic algorithm was applied to solve the optimal design problem including the optimization of equipment type and capacity for a trigeneration system. On the other hand, Shariatzadeh et al. [11] presented a single-objective optimization of a trigeneration system fed by biogas, considering cost as the function of the goal of the model through the genetic algorithm. Cost analysis tools are common used methodologies for energy planning and management. They have been used in the more 17 articles. These are generally used as auxiliary methods, which are a method which is breakeven point analysis [46], cost-benefit analysis [47],[48], etc. with the main solution. 
Dufo-López et al. [49], simulated a diesel-battery system presented for an off-grid hospital in a stochastic approach using a monte carlo simulation to evaluate the performance of the system. Duki et al. [50] have used monte carlo simulation to model errors in the electricity and thermal load forecast that they all are stochastic variables. Mavrotas et al. [19], presented a combined method with monte carlo simulation and mixedinteger linear programming (MILP) to build an integrated energy planning under uncertainty for a hospital in Athens. Mixed-Integer Nonlinear Programming (MINLP) is mathematical programming that contains discrete and continuous variables and its objective function and constraints are nonlinearities. This method has been used depending on the complexity of the energy problems in some studies. For example, Li et al. used a MINLP model that includes three aspects of energy demands that they are $\mathrm{x}$ (design variables $=$ facility capacities, maximum purchased gas and electricity) y and $\mathrm{z}$ (continuous and integer operation variables) [51]. In the same manner, Azit et al. [52], tried to define the optimal capacity of a CHP system using the MINLP method. In another study, Jing R. et al. proposed to optimize system design and operation simultaneously for solid oxide fuel cells (SOFCs) based combined cooling, heating and power system (CCHP) with MINLP because there are two unknown parameters are the installed capacities and dispatch strategy of the proposed system[53]. The other method is Artificial Neural Network (ANN) used to forecast energy demands depended on some parameters. For example, an electricity load forecasting model for a healthcare clinic was performed with the implementation of an Artificial Neural Network (ANN) which is based on a backpropagation training algorithm that has loaded, data concerning the type of day, time of the day and weather data such inputs [54]. Wu Q et al. examined the influences of building type and climate on the performance trigeneration system in four type buildings (hospital, hotel, office, store) located in 6 main climates in Japan using a multi-criteria assessment method which is analytic hierarchy process (AHP) has three parameters are PES, TCS and $\mathrm{CO}_{2}$ concentration [55]. Table 5 shows the list of the studies used IE and OR methods by years. Mavrotas G. et al. [19], has represented an explanatory use of the example of MILP was the most used method in energy planning for healthcare facilities. They have shown a hospital's energy infrastructure as shown in Figure 10 below.

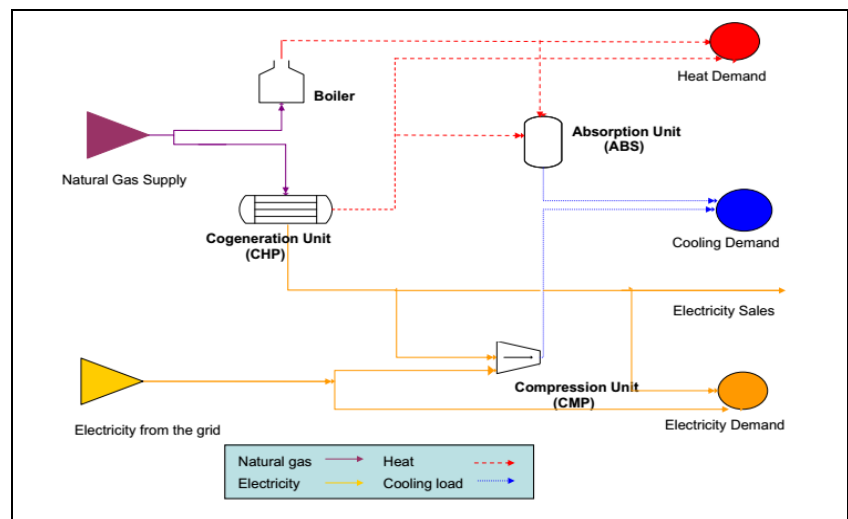

Figure 10. The superstructure of the hospital's energy system [19].

Table 5. List of studies used IE and OR methods by years.

\begin{tabular}{|c|c|c|c|c|c|c|c|c|c|c|c|c|c|}
\hline $\begin{array}{l}\text { IE or OR } \\
\text { Methods }\end{array}$ & $\begin{array}{c}200 \\
6 \\
\end{array}$ & 2007 & 2008 & 2009 & 2010 & 2011 & 2012 & 2013 & 2014 & 2015 & 2016 & 2017 & 2018 \\
\hline \multicolumn{14}{|l|}{ Mixed } \\
\hline $\begin{array}{l}\text { Integer } \\
\text { Linear }\end{array}$ & & $\begin{array}{c}{[8],[21],} \\
{[22],}\end{array}$ & [30] & & [19] & [25], & [32], & {$[6],[29]$} & [20],[28], & & [27], & [35],[39], & \\
\hline $\begin{array}{l}\text { Programming } \\
\text { (MILP) }\end{array}$ & & [23] & & & & & & & & & & & \\
\hline \multicolumn{13}{|l|}{$\begin{array}{l}\text { Cost Analysis } \\
\text { Methods }\end{array}$} & \\
\hline \multicolumn{13}{|l|}{$\begin{array}{l}\text { Break Event } \\
\text { Point etc.) }\end{array}$} & [166] \\
\hline \multicolumn{14}{|l|}{ Statistical } \\
\hline $\begin{array}{l}\text { Methods } \\
\text { (Regression } \\
\text { Analysis and }\end{array}$ & & & & & & [86] & [141] & [102] & {$[104],[106]$} & $\begin{array}{c}{[43],[76],} \\
{[138]}\end{array}$ & $\begin{array}{c}{[85],} \\
{[12],[8],} \\
{[143]}\end{array}$ & {$[57],[159]$} & [172] \\
\hline $\begin{array}{l}\text { Analysis and } \\
\text { Models etc.) }\end{array}$ & & & & & & \\
\hline $\begin{array}{l}\text { Genetic } \\
\text { Algorithms } \\
\text { (GA) }\end{array}$ & & & & & [40] & & & $\begin{array}{c}{[4],[6],} \\
{[98]}\end{array}$ & & $\begin{array}{c}{[11],[42],} \\
{[43]}\end{array}$ & $\begin{array}{l}{[44],} \\
{[45]}\end{array}$ & [156] & \\
\hline $\begin{array}{l}\text { Monte Carlo } \\
\text { Simulation }\end{array}$ & & & & & [19] & & [50] & [98] & & & $\begin{array}{l}\text { [49], } \\
{[85]}\end{array}$ & & [175] \\
\hline \multicolumn{14}{|l|}{$\begin{array}{l}\text { Mixed } \\
\text { Integer }\end{array}$} \\
\hline Nonlinear & & & [51] & [52] & & [88] & & & & & & [53] & \\
\hline \multicolumn{14}{|l|}{$\begin{array}{l}\text { Programming } \\
\text { (MINLP) }\end{array}$} \\
\hline \multicolumn{14}{|l|}{ Artificial } \\
\hline $\begin{array}{c}\text { Neural } \\
\text { Networks } \\
\text { (ANN) }\end{array}$ & & & & & & & & [70] & {$[54],[42]$} & & & [172] \\
\hline $\begin{array}{l}\text { Stochastic } \\
\text { Programming }\end{array}$ & & & & & & & [50] & [98] & & & & [35] & [175] \\
\hline \multicolumn{14}{|l|}{$\begin{array}{l}\text { Programming } \\
\text { Multi-Criteria }\end{array}$} \\
\hline Decision & & & & & & & & & {$[55]$} & & [119] & {$[58]$} & \\
\hline $\begin{array}{l}\text { Making } \\
\text { Methods }\end{array}$ & & & & & & & & & {$[35]$} & & {$[119]$} & {$[58]$} & \\
\hline Methods & & & & & & & & & & & & & \\
\hline $\begin{array}{c}\text { Fuzzy } \\
\text { Programming }\end{array}$ & & & [30] & & & & & [97] & & & & & \\
\hline $\begin{array}{l}\text { System } \\
\text { Dynamics }\end{array}$ & & & & & & & & & & & & & [165] \\
\hline
\end{tabular}


A MILP model is formulated for the cost optimization of the energy superstructure shown in Figure 10. In their model, they used demand data for the three types of load, namely heating, cooling, and electricity, which are given on an hourly basis for a typical day of each month. Furthermore, they used continuous decision variables that indicate energy flows and equipment capacities, while binary decision variables refer to the adoption or rejection of the considered types of units, as well as to the operation of a unit during a period. To maintain the linear characteristics of the model, they were used piecewise linear approximations for the characteristics of the equipment as a function of its capacity. The objective function, constraints, and parameters in the model are as follow [19];

\section{Objective function;}

The objective function that expresses the minimization of the annualized energy cost is given by the following equation (1):

$$
\begin{aligned}
\min _{1}=\sum_{k=e l, n g} c^{k} & \text { ENERGY } Y^{k}-p^{e l s} \text { ELCHPS } \\
& +\sum_{m=1}^{4}\left(i c p t^{m} B^{m}+\operatorname{slop}^{m} C A P^{m}\right)
\end{aligned}
$$

Where

- $\quad E N E R G Y^{k}$ is the purchased amount of energy of kth type ( $k=$ electricity from the grid and natural gas), $c^{k}$ is the corresponding cost,

- $\quad p^{e l s}$ is the selling price of the electricity from the CHP to the grid,

- $\quad$ ELCHPS the electric energy from the CHP that is sold to the grid

- $\quad m$ is the index for the different units.

- The parameters $i c p t^{m}$ and slop $^{m}$ are the intercepts and the slope respectively of the line expressing the annualized cost of the unit (investment and O\&M) as a function of unit capacity drawn from available cost data of various units.

- The decision variables $B^{m}$ and $C A P^{m}$ express the existence or not of $m$ th unit (binary variable) and the capacity of mth unit respectively.

Constraints

Constraints are related to demand, capacities and energy balances,

Demand satisfaction: The heat, electricity and cooling load produced in the network must meet the corresponding demands in each period as given Eq (2). In the case of electricity, exchanges with the grid are possible:

$$
P O W E R_{i j}^{k} \geq l d_{i j}^{k} \quad i=1 \ldots s, j=1 \ldots p, k=\text { elec, heat,cool }
$$

Where, $s$ and $p$ denote the number of seasons and periods of the day respectively, $P O W E R^{k_{i j}}$ is the decision variable denoting the required output for serving the kth load in season $i$ and period $j$, and $l d k_{i j}$ is the parameter that expresses the required load of kth type in the ith season and the jth period of day.

Energy balances: They refer to energy inputs and outputs from the CHP, absorption and compression units and the boiler for each period. Therefore, for the mth unit the energy balance for season $i(i=1 \ldots \mathrm{s})$ and period of day $j(j=1 \ldots p)$ becomes as described in Eq (3):

$$
\begin{gathered}
e f f^{m} I N P U T_{i j}^{m}-O U T P U T_{i j}^{m}=0 \quad i=1 \ldots S, j=1 \ldots p, \\
m=1 \ldots 4
\end{gathered}
$$

where eff $m$ is the efficiency of the $m$ th unit, INPUTm $m_{i j}$ is the variable indicating the power input for unit $m$ (in terms of power) referring to season $i$ and day $j$, while OUTPUT $m_{i j}$ is the corresponding output.

Equipment capacity: They set the corresponding upper bound to the output of each unit in each period, whether the latter is a parameter (i.e. for existing units such as the boiler) or a decision variable (i.e. for new units such as CHP, absorption and compression units) (See Eq 4-5).

$$
\begin{gathered}
C A P^{m}-l o^{m} B^{m} \geq 0 \& C A P^{m}-u p^{m} B^{m} \leq 0 \quad m=1 \ldots 4 \\
\text { OUTPUT } T_{i j}^{m}-C A P^{m} \leq 0 \quad i=1 \ldots S, \quad j=1 \ldots p, m=1 \ldots 4
\end{gathered}
$$

Where,

CAPm is the decision variable indicating the capacity of unit m, $\mathrm{Bm}$ is the binary decision variable indicating the existence or not of the mth unit, while lom and upm are the parameters indicating the lower and upper bound for these capacities.

Technical minimum: These constraints set, Eq. 6-7, as the corresponding lower bound to the output of each unit in each period (usually $30 \%$ of its nominal capacity). There are binary variables for each unit $\mathrm{m}$, indicating if the unit is operating or not in the ith season and the jth period of day (Ymij). These variables are necessary for modeling the technical minimum requirement.

$$
\begin{gathered}
\operatorname{OUTPUT}_{i j}^{m}-u p^{m} Y_{i j}^{m} \leq 0 \quad i=1 \ldots s, \quad j=1 \ldots p, m=1 \ldots 4 \\
\left(\operatorname{tmin}^{m} u p^{m}\right) i=1 \ldots s, \quad j=1 \ldots p, m=1 \ldots 4
\end{gathered}
$$

Where,

$t_{m i n}$ is the technical minimum of the mth unit as the percentage of the unit's capacity. If $Y^{m} i j=1$ the constraint is activated while if $Y^{m} i j=0$ it becomes inactive.

Reserve margin for cooling load: The sum of capacities of the compression and the absorption unit should be $20 \%$ greater than the annual hourly peak in cooling load (maxcldm) as given Eq 8.

$$
C A P^{a b s}+C A P^{c m p} \geq 1.2 \text { maxcldm }
$$

CHP modeling: The CHP unit is modeled by using two size domains: from 50 to $200 \mathrm{~kW}$ and from 201 to $400 \mathrm{~kW}$ with different investment cost and technical characteristics (i.e. efficiency and power to heat ratio) as shown in Eq 9-12.

$$
\begin{gathered}
C A P_{v}-\operatorname{locap}_{v} S_{v} \geq 0 \quad v=1,2 \\
C A P_{v}-\operatorname{upcap}_{v} S_{v} \leq 0 v=1,2 \\
C A P^{\operatorname{chp}}-\sum_{v} C A P_{v}=0 \\
S_{1}+S_{2} \leq 1
\end{gathered}
$$

$S_{v}$ is the binary variable indicating the size domain where the selected CHP unit belongs $(v=1,2)$. The binary variables $S_{v}$ are also used to link electricity and heat production through the appropriate power to heat ratio (see Eq. 13): 


$$
E L_{i j}-\sum_{v} p h_{v} H T_{v i j}=0 i=1 \ldots s, j=1 \ldots p
$$

Where,

$p h_{v}$ is the power to heat ratio for the vth type,

$E L_{i j}$ is the electricity output of the CHP unit in season $i$ and period $j$,

$H T_{v i j}$ is the heat output of the CHP unit of vth type in season $i$ and period $j$.

In order to deactivate the redundant $H T_{v i j}$ variables (corresponding to the vth type of CHP unit that is not selected), it is added the two following constraints (see Eq. 14-15):

$$
\sum_{i j} H T_{v i j}-\left(2 s p u p_{v}\right) S_{v} \leq 0 v=1,2
$$

Where,

$u p_{v}$ is the upper bound on the capacity for the CHP unit of vth type (factor 2 is added because capacity is defined in terms of electric output and the thermal output is at least $1 \frac{1 / 2}{2}$ times higher).

Conversion of power to energy: Annual energy figures are obtained by summing the products of the number of hours in each day-period of a season with the respective load (heating, cooling or electricity).

$$
E N E R G Y^{k}-\sum_{i j} h_{i j} P O W E R_{i j}^{k}=0 \quad k=1 \ldots K
$$

Where,

$E N E R G Y^{k}$ is the total annual energy for the kth load,

$h_{i j}$ is the parameter indicating the number of hours in the ith season and the $j$ th period of day, POWER ${ }^{k}$ ij is the respective power of the kth load,

$K$ is the number of different energy forms that we need to calculate.

\subsection{Alternative energy technologies/sources and results}

Healthcare facilities have complex energy systems and use conventional energy sources, mainly electricity, natural gas, and heating oil. In the conventional hospital energy system, electricity demand is satisfied from the local utility grid or competitive electric provider. Heat and domestic water needs are met by multiple natural gas or coal-fired boilers, which generate steam or hot water, based on the principle of hot water loop or steam loop. On the other hand, the cooling energy need for healthcare facilities is met by using electric chillers with a chilled water loop that operated on electric power supplied from the local utility, or by absorption chillers in conjunction with electric chillers as auxiliary to offset peak electric demands. Without the use of renewable energy sources, each type of energy is generally derived from independent structures, which are not integrated into conventional energy systems, so energy consumption in these systems is generally very large and energy costs are very high. Besides that, many healthcare facilities have inefficient and crumbly central energy plants and systems. Therefore, healthcare professionals seek cost-effective ways for updating outdated energy infrastructure, while minimizing risk and positioning vital systems for the future and making them based on renewable sources. For all these reasons, the subjects related to the use of alternative technologies and renewable sources for healthcare facilities is a trending topic in the literature. The improved alternative energy technologies and various renewable energy sources have been used over time to cover healthcare facilities' energy requirements resulting in high $\mathrm{CO}_{2}$ emissions and to reduce energy consumption and energy costs. Figure 11 shows the using of type of alternative energy technologies and sources for healthcare facilities as per literature studies, whereas Figure 12 shows the distribution and the use of alternative energy technologies and sources by years in the studies.

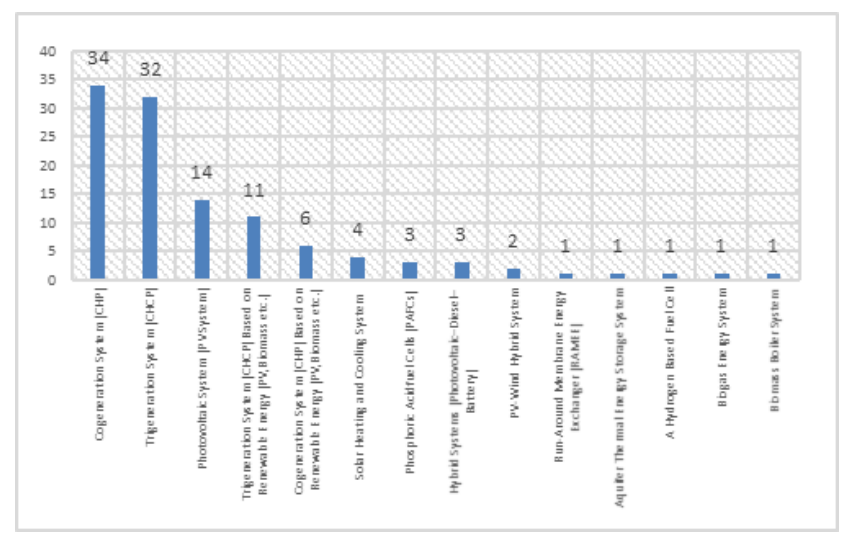

Figure 11. The Use of alternative energy technologies and sources in relevant articles.

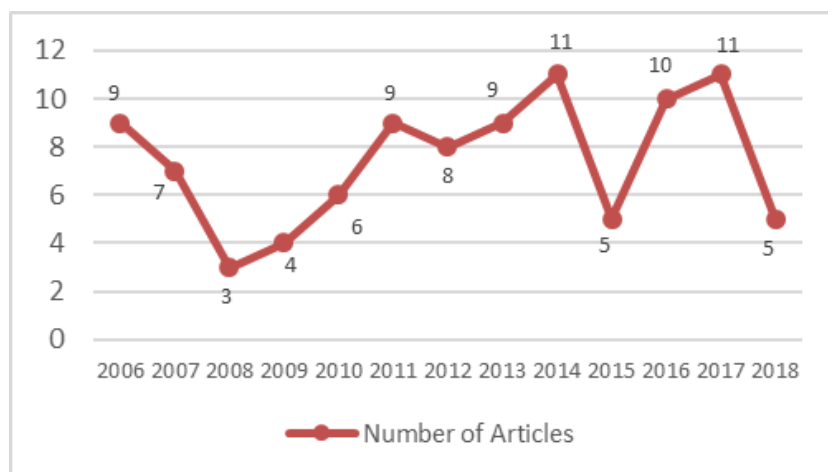

Figure 12. The distribution of alternative energy technologies and sources in relevant article by years.

We think that the situation of becoming more studies about cogeneration or trigeneration is related to some advantages of these systems, such as to be suitable for large buildings from the point of energy consumption, to have short-term breakeven point, minimizing waste of energy and to obtain several types of energy forms simultaneously. Table 6 shows a list of the studies that were subjected to alternative technology and sources by years.

The most used alternative energy applications in the relevant studies are Combined Heating, Power (CHP) and Combined Heating, Cooling and Power (CHCP) systems, which ensure maximum energy efficiency by minimizing energy waste. Using a cogeneration or trigeneration system in a healthcare facility is an ideal method of achieving improved energy efficiency and reduced carbon emissions.

Their utilization, with reducing energy costs, helps a healthcare facility's limited financial resources go further. These systems not only are energy-efficient applications but also they are so costly that they need to be custom designed very well from the point of energy costs, investment payback period and 
environmental aspects. On the other hand, hospitals are among the best practice areas for CHP and CHCP systems, since they have almost constant electricity, heat, hot water, and cooling demands. CHP and CHCP applications in healthcare facilities generally are working depending on the grid electricity system and natural gas as fuel input. In many relevant studies, various solution methods have been applied for the purpose of obtaining minimum operating cost, optimal operating method and ensuring maximum efficiency for these systems, whereas some studies have proposed to put forth a framework related to comparing of application of these systems for healthcare facilities and equivalent buildings such as hotel, office and shop center $[39,55,56,57,58]$.

Al-Mansour F. et al. [41], developed software to consider a cogeneration system from the point of economic aspects and to evaluate the economic risk for the system. Oh SD et. al [21] determined the optimal system furnishing and the optimum operating mode of a CHP system based on the annual cost method for a healthcare facility and some apartments in Seoul, Korea by using the data of annual demands of electricity, heating, and cooling. In the another study, Alexis et. al. implied that a hospital is a possible nominee for the implementation of a cogeneration system and their study showed that when the main gas engine (Diesel with natural gas) operates $8000 \mathrm{~h} /$ year and the backup unit $5000 \mathrm{~h}$ /year, the cogeneration system is most economically profitable [25]. Arcuri P. et al. [8], has presented how it is necessary and important to be able to determine the optimal plant design and its running conditions for a trigeneration system in a hospital with the aim of making investment decisions as a function of all the variables in play, above all in the energetic sector characterized by tariff policies and a market in continuous evolution.

Zheng CY. et al. [9], forth a new operation strategy for the trigeneration system by comparing with FEL (following the electric load), FTL (following the thermal load) and FHL (following hybrid electric-thermal load) strategies. Wu Q et al. examined the influences of building type and climate condition on the introduction of trigeneration systems, four representative commercial building categories (hotel, hospital, store, and office) located in six major climate zones in Japan are compared and evaluated by using a multi-criteria evaluation method included energy, economic and environmental aspects. According to the assessment results, the trigeneration systems in hotels and hospitals enjoy better overall performances than those in stores and offices [55].

CHP and CHCP systems sometimes were used based on renewable energy sources which are photovoltaics $[3],[6],[59],[34],[44],[60],[61]$, biomass [11],[62],[63],[64], high temperature fuel cell [65], solar thermal collectors [66] and solid oxide fuel cells (SOFCs) [53]. For example, Isa NM et. al. [3], aimed to assess the viability to develop a cogeneration system for a hospital building load in Malaysia which consists of grid-connected photovoltaic (PV), fuel cell, and battery.

Table 6. List of studies used alternative technology and sources by years.

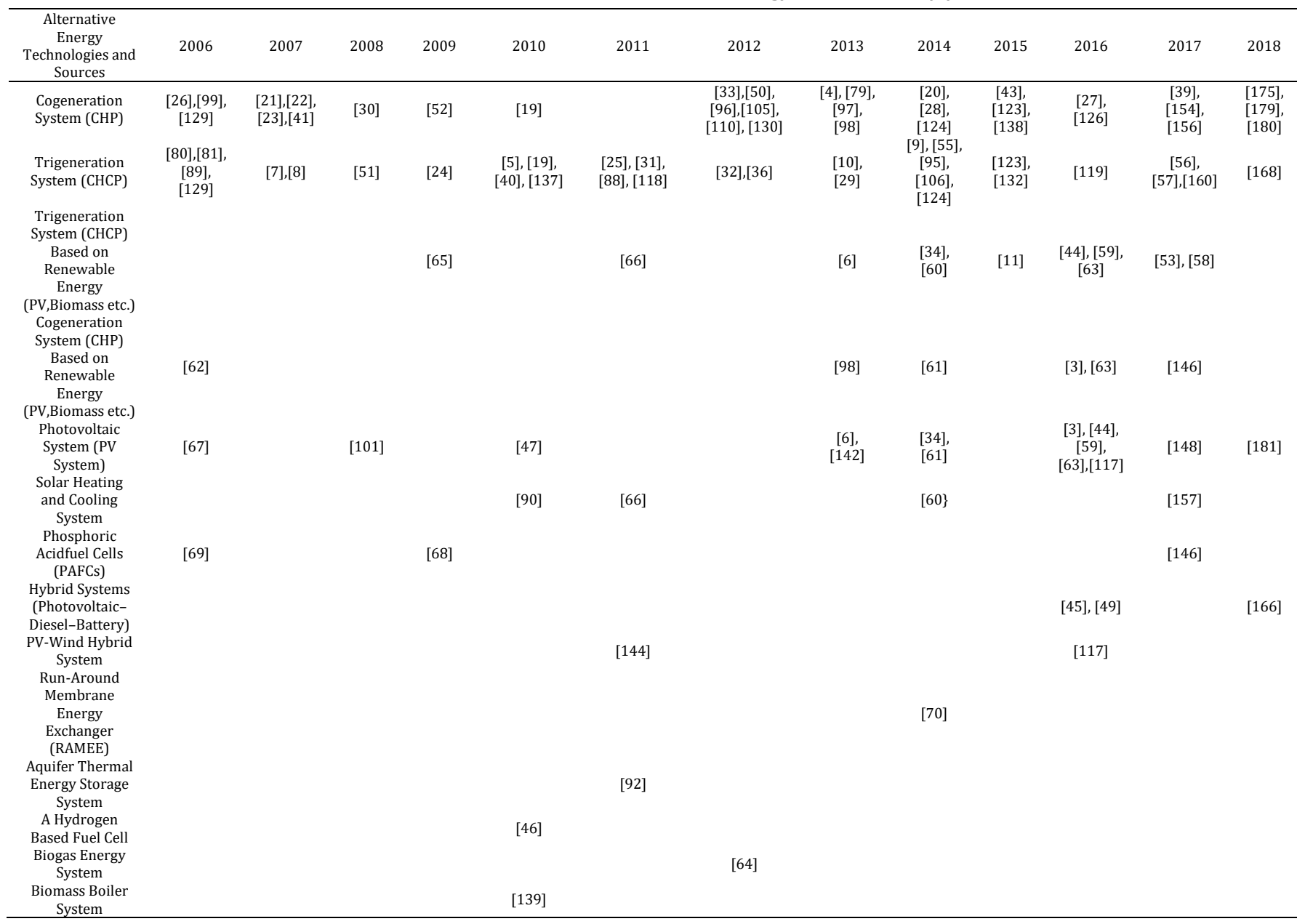


Photovoltaic systems or a hybrid system with photovoltaic have been studied to fulfill the electricity demand of healthcare facilities. For instance, Al-Karaghouli et al. [47] addressed the requirement for electricity of rural areas in southern Iraq and proposed a photovoltaic (PV) solar system to power a health clinic in that region. Pradhan et al. analyzed three renewable energy source options which are solar photovoltaic, wind energy system and PV-wind hybrid system. The obtained simulation results indicated that the PV-wind hybrid system has the lowest unit cost of energy as compared to an independent solar photovoltaic or wind energy system [48]. The other hybrid system with photovoltaic is photovoltaic-diesel-battery system which was studied in [45],[49]. Dufo-López R. et al. [49], presented a methodology to optimize electrical supply for an off-grid hospital located in Kalonge (the Democratic Republic of the Congo) that the optimization includes the possibility of adding solar photovoltaic (PV) panels to improve the supply of electrical energy.

Besides the aforementioned alternative energy applications and sources, many technologies and sources have been studied in the relevant papers that some of them are phosphoric acid fuel cells (PAFC) [67]-[69], run-around membrane energy exchanger (RAMEE) [70], hydrogen-based fuel cell [46].

The use of alternative energy sources and technologies in healthcare facilities is widespread considering the literature. The conducted studies related to several kinds of energy resources and technologies indicate that healthcare facilities are quite convenient to apply new energy sources and technologies because of their increasing energy consumptions include electricity, heat, cooling and hot water.

\subsection{Renovation/Refurbishment activities for energy efficiency and results}

Reducing of energy consumption in buildings could be achieved by taking effective measures, which are sustainable energy-saving activities and consciousness-raising of users about energy consumption in existing buildings. The energy savings can be ensured by the best and most cost-effectively when the work is done at the same time as the general building renovation and refurbishment activities such as replacing the roofs or windows, replacing magnetic ballasts with more efficient electronic ballasts or renovating outside walls, etc. Energy renovation/refurbishment activities also help to increase the quality of buildings because they can improve the indoor climate, thermal comfort, and daylight conditions, making the buildings healthier and better to be lived and work in. Renovation/refurbishment of buildings is generally costly activities, so these activities should be planned very well and investment costs, payback time and energy-saving potential must be considered. In the literature, many studies have been conducted about renovation/refurbishment activities to save energy in healthcare facilities. This section mainly related to the studies, which focused on existing healthcare facilities and improvements that can be made through the adaptation and implementation of energy efficiency measures by making renovation/refurbishment activities. Kolokotsa et al. aimed to analyze the state-of-the-art in the technological applications and energy-saving techniques in the hospitals what they were classified as the main titles and their relevant energy-saving issues as in the example of heating system title and "Insulation of hot water tanks and boilers" of its energy-saving method [12]. Buonomano A. et al. investigated several actions for the energy refurbishment of some buildings of the University Hospital Federico II of Naples which they are i) roofs thermal insulation; ii) a substation climatic 3-way valve; iii) radiators thermostatic valves; iv) AHU (air handling unit) timeprogrammable regulation. The analysis of them indicated that the buildings of this Hospital need high amounts of energy for space heating and cooling and as a result of this conclusion, such high energy consumption is not only caused by the user habits, since a significant amount of energy is due to the inefficiencies of the building envelope and the HVAC system [71]. Principi et al. were interested in related to an Energy Performance Contracting (EPC) based on renovation/refurbishment activities to apply three acute hospitals and two community clinics built in Italy from the point of economic feasibility. The assessment presented in this paper showed that although the analyzed buildings require enormous amounts of energy for space heating, domestic hot water, and other electric supplies, suitable refurbishment can enhance their performance and reduce their energy consumption by up to $77 \%$ in those cases where "high-cost investments" (acute hospitals) were hypothesized [72]. In the other study, Mohammadpour et al. were focused on the interactions between patient safety and energy efficiency by making retrofit applications in hospitals. With this aim, they developed an innovative integrated framework, the Patient Safety and Energy Efficiency (PATSiE) framework to increase patient safety and energy efficiency simultaneously [73]. As a detailed study, Ascione et al. tried to present a renewed method to define robust cost-optimal energy retrofit solutions in the scope of the 'Energy Performance of Buildings Directive' Recast (i.e., 2010/31/EU) that this methodology includes two optimization stages. The preliminary examination and the first optimization stage, which runs a genetic algorithm, aimed at detecting efficient energy retrofit measures (ERMs) to reduce thermal energy demand for space heating and cooling. In the second optimization stage, these ERMs are combined with further ERMs, addressed to improve the efficiency of energy systems and to exploit renewable energy sources [44].

Figure 13 indicates the distribution of studies related to renovation/refurbishment activities by years for healthcare facilities. The number of studies about renovation/refurbishment is on increase, because they have the added advantage of minimizing the emission of $\mathrm{CO}_{2}$, while rendering the building as energy-efficient as possible.

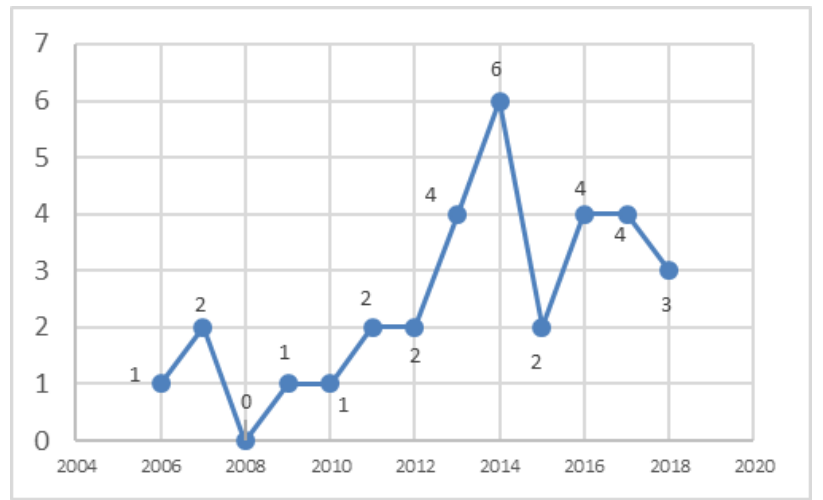

Figure 13. Renovation/Refurbishment activities for energy efficiency in relevant studies. 


\subsection{Analysis of articles based on the used energy forms}

The most used ones of energy forms are electricity, heating (space heating), cooling and hot water in the healthcare facilities. In this review study, relevant studies have been classified according to the energy forms, which were used alone or in a combination of forms. Although It has generally been handled four energy forms together in our relevant studies, electricity power was the most handled alone. Figure 14 shows the type of energy forms and their usage in relevant studies.

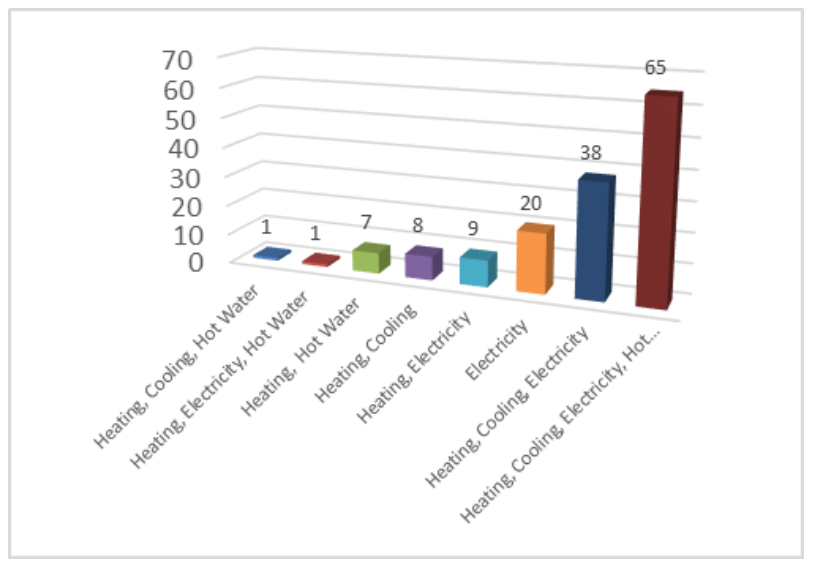

Figure 14. The Use and Combination of Energy Forms in Relevant Articles

Electricity power is the most commonly used energy form, which is a key element for the running of electronic devices (especially medical ones) and all motors, lighting systems, heating/cooling generation systems. Saidur et al. have presented a study about electrical motors to reduce their energy consumption along with emission reduction related to energy savings. In this study, it has been found that lighting covers a great part of total energy consumption (i.e. about $36 \%$ ) followed by medical equipment (i.e. about 34\%) [74]. Morgenstern et al. have presented the electricity use of some department types that have been quantified using on-site measurements. Results verify that different hospital units have hugely varied electricity consumption features [75]. Furthermore, the studies related to photovoltaic energy systems generally have been focused on the production or storage of electrical power. In this context, Al-Karaghouli A. et al. proposed to define the need for electricity for rural areas in southern Iraq and a photovoltaic (PV) solar system has been recommended to satisfy this requirement for a health clinic [76].

One of the most wanted properties in healthcare facilities is suitable thermal comfort because it aids to stabilize the emotional moods of patients and it is helpful for the improvement of their recuperation process. A few of the factors that affect thermal comfort are heating and cooling values of healthcare facilities, which have specific heating and cooling requirements because they are occupied 24 hours per day and 7 days per week for the whole year. Researchers intend to study minimizing energy usage in heating, cooling, ventilating and air conditioning systems in buildings operating with an acceptable thermal comfort level and to improve the performance and well-being of patients. Karakasli et al., has focused on the performance assessment of a polyclinic heating and cooling system in a hospital building. It has been assessed by using energy and exergy analysis methods, which evaluated lots of parameters such as primary energy production, an envelope of the building, total exergy input rate per area, total exergy input rate per volume and exergy flexibility factor [77] The trade-off between thermal comfort and energy saving for heating and cooling is another important factor, so the consumption of heating and cooling energy should be calculated very well. Congradac et al. have developed a program for detecting heating and cooling energy consumption that concentrates on the problem [16]. In another study, Khodakarami et al. examined a range of passive building fabric techniques in two monitored case study hospitals to examine how it can be might best achieve this range of indoor air temperatures, and reduce reliance on heating and cooling systems through modeling [78].

On the other hand, the combination of electricity and heating generally refers that cogeneration was studied, whereas the combination of electricity, heating, and cooling generally refers to a trigeneration study [6],[21],[40],[79]-[81]. For instance, Guo et al. have presented a two-stage optimal planning and design method for combined cooling, heat and power (CCHP) microgrid system where the optimal objective was to simultaneously minimize the total net present cost and carbon dioxide emission in life circle [6].

Additionally, the need for hot water is very important for healthcare facilities from the point of carrying on auxiliary activities such as sterilization, refectory, patient room, etc., so this energy form has been studied as in fourth place in our relevant studies. The use of hot water, which requires very energy-consuming, is high in hospitals. To avoid unnecessary energy consumption for water heating, necessary measures to save energy should be taken such as pipe insulation. Hot water generally was taken into consideration with other forms of energy in particular heating. The most used combination of energy forms is "heating, cooling, electricity and hot water", whereas the combination of "heating and hot water" form is the most representative from the point of hot water that one example is [82] in which, Bujak aimed to analyze the variations and seasonal changes in the heat consumed to produce domestic hot water during the specified time periods.

\section{Conclusions and recommendations}

To our knowledge, this study is the first systematic literature review of energy studies related to healthcare facilities. In this context, some reasons like the gap in the literature about this topic, the growing healthcare sector and increasing its energy consumption, efforts to find alternative energy technologies and sources reducing energy consumption form the impetus for this study. By reviewing and iterating what we know in relation to new ways and solution methods for healthcare facilities' energy applications and how healthcare professionals essentially benefit from this data and information, we think of that this review study can be incentive and assistant for concerned professionals, researchers, practitioners who having the agenda and idea of to study energy applications in healthcare facilities and in the similar buildings (hotels, big trade centers etc.).

This review study has been conducted on the studies in the literature between 2006 and 2018 about energy efficiency/planning/management for healthcare facilities and it has analyzed and classified relevant articles according to their interests with the topic. A multi-phase process was adopted to ensure more completeness to our study when it was retrieved from the relevant studies. Besides that, the 
searching process was divided into two main stages, which are the main stage and the second stage. In the main stage, studies were searched for in the reference database included 54 peerreviewed journals by using keywords to identify relevant studies; some of them were excluded with the criteria of exclusion, whereas relevant studies were included with the analysis of titles and abstracts, and eventually the primary articles were acquired based on full-text reading. In the second stage, studies cited to our primary articles were taken into consideration and relevant studies were selected according to the aforementioned criteria.

Our findings indicate that energy subject in healthcare facilities is fashionable in literature, due to growing energy consumption that causes to apply alternative energy applications and ensures great convenience to investigate huge energy saving potentials. The significant conclusion is that most of the relevant studies have been conducted on 500beds and over hospitals because the efforts are intensely being made to reduce energy consumption in the growing-capacity healthcare facilities. It has learned from this study that the use of alternative energy technologies, especially combined systems based on renewable sources, is quite important to cope with huge energy consumption and to save energy. In the literature, there are many studies affiliated with cogeneration and trigeneration applications, which were studied alone as well as integrally with other systems. Although the studies related to alternative energy technologies like trigeneration have been carried out for big hospitals such as 500-beds and over hospitals, the studies about alternative energy sources like photovoltaic have generally concentrated on small healthcare facilities such as healthcare centers or small offgrid hospitals. Renewable energy is environmentally clean, affordable, domestic, and infinite. We think that there are few studies, not enough, based on different renewable sources for healthcare facilities such as photovoltaic, biomass, solar thermal energy. On the other hand, wind energy option for healthcare facilities has not been evaluated sufficiently in the literature by researchers and practitioners. Despite some its disadvantages, when it is established in productive places in terms of wind, it has many advantages such as no air emissions, continuous production at night and during times when it is cloudy or rainy.

When retrieved relevant studies are analyzed in terms of public or private sector participation, it is seen that the great majority of studies belong to the public sector with $75 \%$ percentage and then public-private partnership and private sector studies come in order. This shows that energy studies related to healthcare facilities generally are performed by universities or academia. We think that studies based on public-private partnership should be increased to facilitate access to actual data, providing a balance of theory/practice and increase the reliability of the applications. On the other hand, mechanical engineering departments have the biggest share with approximately $20 \%$ percentage in the distribution of public education studies based on departments. In our opinion, it is caused by the multiplicity of studies based on mechanical engineering such as cogeneration and trigeneration for healthcare facilities.

To optimize energy systems and minimize energy costs, Industrial Engineering and Operations Research methods were used widely in the literature, especially optimizationbased mathematical approaches such as Mixed Integer Linear Programming (MILP), Genetic Algorithm (GA) and Mixed
Integer Non-linear Programming (MINLP). The production and consumption of energy forms such as electricity and heating in complex buildings like healthcare facilities take place within the network of interconnected energy processes. A change carried out in one energy process affects other energy processes. For these reasons, the energy management of complex buildings includes a large energy system with internal relationships between energy carriers and the equipment, as well as external relations with the environment. On the other hand, the energy demand for such complex buildings like healthcare facilities is generally under uncertainty that causes the need for further approaches to solving energy problems. Agent-Based Simulation seems to be another approach to getting popular in this field. This method with the bottom-up approach is very useful to understand complex systems and it receives drawing attention from many researchers in the field of energy system modeling. We think that these types of methods will be suitable for energy planning and management for healthcare facilities energy problems when used in the studies alone or in an integrated manner with other solution methods.

As a result, when discussing the practical implications of our major findings, this review allows the investors to see the latest energy researches in the field of healthcare management. Also, It reveals the importance of energy in healthcare management and it demonstrates the importance of energy planning in the health sector. This research focuses on the fields of applied mathematics in the field of energy in the health sector. It determines what medical and engineering science can do together. It explores which methods can be used in energy efficiency planning in healthcare management and also, it reveals what kind of problems, Operations Research can solve in the field of energy.

\section{References}

[1] Internet Page.

"European Comission- Topics - Energy".

https://ec.europa.eu/energy/topics/energy

efficiency/energy-efficient-buildings/energy performance-buildings-directive_en (15.10.2016).

[2] Teke A, Timur 0. "Overview of energy savings and efficiency strategies at the hospitals". International Journal of Social, Behavioral, Educational, Economic, Business and Industrial Engineering, 8(1),242-248, 2014.

[3] Isa NM, Das HS, Tan CW, Yatim AHM. "A techno-economic assessment of a combined heat and power photovoltaic/fuel cell/battery energy system in Malaysia hospital". Energy, 112, 75-90, 2016.

[4] Gimelli A, Muccillo M. "Optimization criteria for cogeneration systems: Multi-objective approach and application in an hospital facility". Applied Energy, 104, 910-923, 2013.

[5] Kavvadias KC, Tosios AP, Maroulis ZB. "Design of a combined heating, cooling and power system: Sizing, operation strategy selection and parametric analysis". Energy Conversion and Management; 51, 833-845, 2010.

[6] Guo L, Liu W, Cai J, Hong B, Wang C. "A two-stage optimal planning and design method for combined cooling, heat and power microgrid system". Energy Conversion and Management, 74, 433-445, 2013.

[7] Cardona E, Piacentino E. "Optimal design of CHCP plants in the civil sector by thermoeconomics". Applied Energy, 84, 729-748, 2007. 
[8] Arcuri P, Florio G, Fragiacomo P. "A mixed integer programming model for optimal design of trigeneration in a hospital complex". Energy, 32, 1430-1447, 2007.

[9] Zheng CY, Wu JY, Zhai XQ. "A novel operation strategy for CCHP systems based on minimum distance". Applied Energy, 128, 325-335, 2014.

[10] Facci AL, Andreassi L, Martini F, Ubertini S. "Optimization of CHCP operation strategy: Cost vs primary energy consumption minimization". ASME International Mechanical Engineering Congress and Exposition, Proceedings (IMECE), USA, 15-21 November 2013.

[11] Shariatzadeh OJ, Refahi AH, Rahmani M, Abolhassani SS. "Economic optimisation and thermodynamic modelling of SOFC tri-generation system fed by biogas". Energy Conversion and Management, 105, 772-781, 2015.

[12] Kolokotsa D, Tsoutsos T, Papantoniou S. "Energy conservation techniques for hospital buildings". Advances in Building Energy Research, 6(1),159-172, 2012.

[13] Marshall B, Rashid F. "The Ottawa Hospital Energy Management Program". Journal of the Association of Energy Engineers, 110(3), 65-80, 2013.

[14] Bonnema E, Pless S, Doebber I. "Advanced Energy Design Guide for Small Hospitals and Healthcare Facilities". Journal of Healthcare Engineering, 1(2), 277-196, 2010.

[15] Martini I, Discoli C, Rosenfeld E. "Methodology developed for the energy-productive diagnosis and evaluation in health buildings". Energy and Buildings, 39, 727-735, 2007.

[16] Congradac V, Prebiracevic B, Jorgovanovic N, Stanisic D. "Assessing the energy consumption for heating and cooling in hospitals". Energy and Buildings, 48, 146-154, 2012.

[17] Kitchenham B, Charters S. Guidelines for performing systematic literature reviews. Softw Eng 2007.

[18] Internet Page.

"Elsevier-Solutions-Scopus".

https://www.elsevier.com/solutions/scopus (15.10.2016)

[19] Mavrotas G, Florios K, Vlachou D. "Energy planning of a hospital using Mathematical Programming and Monte Carlo simulation for dealing with uncertainty in the economic parameters". Energy Conversion and Management, 51, 722-731, 2010.

[20] Costa A, Fichera A. "A mixed-integer linear programming (MILP) model for the evaluation of CHP system in the context of hospital structures". Applied Thermal Engineering; 71, 921-929, 2014.

[21] Oh SD, Lee HJ, Jung JY, Kwak HY. "Optimal planning and economic evaluation of cogeneration system". Energy, 32, 760-771, 2007.

[22] Yoshida S, Ito K, Yokoyama R. "Sensitivity analysis in structure optimization of energy supply systems for a hospital". Energy Conversion and Management, 48, 2836-2843, 2007.

[23] Chinese D, Meneghetti A, Nardin G, Simeoni P. "From hospital to municipal cogeneration systems: An Italian case study". International Journal of Energy Resources, 31, 829-848, 2007.

[24] Lozano MA, Ramos JC, Carvalho M, Serra LM. "Structure optimization of energy supply systems in tertiary sector buildings". Energy and Buildings, 41, 1063-1075, 2009.
[25] Carvalho M, Serra LM, Lozano MA. "Optimal synthesis of trigeneration systems subject to environmental constraints". Energy, 36, 3379-3790, 2011.

[26] Renedo CJ, Ortiz A, Manana M, Silio D, Pe'rez S. "Study of different cogeneration alternatives for a Spanish hospital center", Energy and Buildings, 38, 484-490, 2006.

[27] Wu Q, Ren H, Gao W, Ren J. "Multi-objective optimization of a distributed energy network integrated with heating interchange". 109, 353-364, 2016.

[28] Romero A, Carvalho M, Millar DL. "Application of a polygeneration optimization technique for a hospital in Northern Ontario". Transactions of the Canadian Society for Mechanical Engineering, 38, 45-62, 2014.

[29] Carvalho M, Lozano MA, Ramos J, Serra LM. "Synthesis of trigeneration systems: Sensitivity analyses and resilience". The Scientific World Journal, 2013. doi: org/10.1155/2013/604852.

[30] Mavrotas G, Diakoulaki D, Florios K, Georgiou P. "A mathematical programming framework for energy planning in services' sector buildings under uncertainty in load demand: The case of a hospital in Athens". Energy Policy, 36, 2415-2429, 2008.

[31] Lozano MA, Carvalho M, Serra LM. "Allocation of economic costs in trigeneration systems at variable load conditions". Energy and Buildings, 43, 2869-2881, 2011.

[32] Carvalho M, Lozano MA, Serra LM. "Multicriteria synthesis of trigeneration systems considering economic and environmental aspects". Applied Energy, 91, 245-254, 2012.

[33] Rezvan AT, Gharneh NS, Gharehpetian GB. "Robust optimization of distributed generation investment in buildings". Energy, 48, 455-463, 2012.

[34] Akbari K, Nasiri MM, Jola F, Ghaderi SF. "Optimal investment and unit sizing of distributed energy systems under uncertainty: A robust optimization approach". Energy and Buildings, 85, 275-286, 2014.

[35] Yang Y, Zang S, Xiao Y. "Optimal design of distributed energy resource systems based on two-stage stochastic programming". Applied Thermal Engineering, 110, 1358-1370, 2017.

[36] Pagliarini G, Corradi C, Rainieri S. “Hospital CHCP system optimization assisted by TRNSYS building energy simulation tool". Applied Thermal Engineering, 44, 150$158,2012$.

[37] Fraile JC, San-José J, González-Alonso A. “A Boiler room in a 600-bed hospital complex: study, analysis, and implementation of energy efficiency improvements". Energies, 7, 3282-3303, 2014.

[38] Wang T, Li X, Liao PC, Fang D. "Building energy efficiency for public hospitals and healthcare facilities in China: Barriers and drivers". Energy, 103, 588-597, 2016.

[39] Nagao H, Uemichi A, Yamasaki Y, Kaneko S. "Proposal of a decision scheme for installing a cogeneration system considering disaster risks". Applied Thermal Engineering, 114, 1414-1423, 2017.

[40] Kavvadias KC, Maroulis ZB. "Multi-objective optimization of a trigeneration plant". Energy Policy, 2010, 38, 945954.

[41] Al-Mansour F, Kožuh M. "Risk analysis for CHP decision making within the conditions of an open electricity market" Energy, 32, 1905-1916, 2007. 
[42] Papantoniou S, Kolokotsa D, Kalaitzakis K. "Building optimization and control algorithms implemented in existing BEMS using a web based energy management and control system". Energy and Buildings, 98, 45-55, 2015.

[43] Muccillo M, Gimelli A, Sannino R. "Multi-objective optimization and sensitivity analysis of a cogeneration system for a hospital facility". Energy Procedia, 81, 585-596, 2015.

[44] Ascione F, Bianco N, De Stasio C, Mauro GM, Vanoli GP. "Multi-stage and multi-objective optimization for energy retrofitting a developed hospital reference building: A new approach to assess cost-optimality". Applied Energy, 174, 37-68, 2016.

[45] Cristóbal-Monreal IR, Dufo-López R. "Optimisation of photovoltaic-diesel-battery stand-alone systems minimising system weight". Energy Conversion and Management, 119, 279-288, 2016.

[46] Munuswamy S, Nakamura K, Katta A. "Comparing the cost of electricity sourced from a fuel cell-based renewable energy system and the national grid to electrify a rural health centre in India: A case study". Renewable Energy, 36, 2978-2983, 2011.

[47] Al-Karaghouli A, Kazmerski LL. "Optimization and lifecycle cost of health clinic PV system for a rural area in southern Iraq using HOMER software". Solar Energy, 84, 710-714, 2010

[48] Dezfouli MMS, Moghimi S, Azizpour F, Mat S, Sopian K. "Feasibility of Saving Energy by Using VSD in HVAC System, A Case Study of Large Scale Hospital in Malaysia". WSEAS Transactions on Environment and Development, 10, 15-25, 2014.

[49] Dufo-López R, Pérez-Cebollada E, Bernal-Agustín JL, Martínez-Ruiz I. "Optimisation of energy supply at offgrid healthcare facilities using Monte Carlo simulation". Energy Conversion and Management, 113, 321-330, 2016.

[50] Duki EA. "Optimal sizing of CHP for residential complexes by two-stage stochastic programming". 2012 Proceedings of $17^{\text {th }}$ Conference on Electrical Power Distribution, Iran, EPDC; 2-3 May 2012.

[51] Li CZ, Shi YM, Huang XH. "Sensitivity analysis of energy demands on performance of CCHP system". Energy Conversion and Management, 49, 3491-3497, 2008.

[52] Azit AH, Nor KM. "Optimal sizing for a gas-fired gridconnected cogeneration system planning". IEEE Transactions on Energy Conversion, 24(4), 950-958, 2009.

[53] Jing R, Wang M, Wang W, Brandon N, Li N, Chen J, Zhao Y. "Economic and environmental multi-optimal design and dispatch of solid oxide fuel cell based CCHP system". Energy Conversion and Management, 154, 365-379, 2017.

[54] Bagnasco A, Fresi F, Saviozzi M, Silvestro F, Vinci A. "Electrical consumption forecasting in hospital facilities: An application case". Energy and Buildings, 103, 261-270, 2015.

[55] Wu Q, Ren H, Gao W, Ren J. "Multi-criteria assessment of combined cooling, heating and power systems located in different regions in Japan". Applied Thermal Engineering, 73, 660-670, 2014.

[56] Feng L, Jiang XZ, Chen J, Ma Y, Shi L. "Time-based category of combined cooling, heating and power (CCHP) users and energy matching regimes". Applied Thermal Engineering, 127, 266-274, 2017.
[57] Biglia A, Carreda FV, Fabrizio E, Filippi M, Mandas N. "Influence analysis of building energy demands on the optimal design and performance of CCHP system by using statistical analysis". Energy and Buildings, 153, 297-316, 2017.

[58] Jing R, Wang M, Brandon N, Zhao Y. "Multi-criteria evaluation of solid oxide fuel cell based combined cooling heating and power (SOFC-CCHP) applications for public buildings in China". Energy, 141, 273-289, 2017.

[59] Wu Q, Ren H, Gao W, Ren J. "Modeling and optimization of distributed energy supply network with power and hot water interchanges". Applied Thermal Engineering, 94, 635-643, 2016.

[60] Buonomano A, Calise F, Ferruzzi G, Vanoli L. "A novel renewable polygeneration system for hospital buildings: Design, simulation and thermo-economic optimization". Applied Thermal Engineering, 67, 43-60, 2014.

[61] Kayo G, Hasan A, Siren K. "Energy sharing and matching in different combinations of buildings, CHP capacities and operation strategy". Energy and Buildings, 82, 685-695, 2014.

[62] Pavlas M, Stehlik P, Oral J, S`ikula J. "Integrating renewable sources of energy into an existing combined heat and power system". Energy, 31, 2499-2511, 2006.

[63] Taseli BK, Kilkis B. "Ecological sanitation, organic animal farm, and cogeneration: Closing the loop in achieving sustainable development-A concept study with on-site biogas fueled trigeneration retrofit in a 900-bed university hospital". Energy and Buildings, 129, 102-119, 2016.

[64] Kantola M, Saari A. "Renewable vs. traditional energy management solutions-a finnish hospital facility case". Renewable Energy, 57, 539-545, 2013.

[65] Malico I, Carvalhinho AP, Tenreiro J. "Design of a trigeneration system using a high temperature fuel cell". International Journal of Energy Resources, 33, 144-151, 2009.

[66] Fabrizio E. "Feasibility of polygeneration in energy supply systems for health-care facilities under the Italian climate and boundary conditions". Energy for Sustainable Development, 15, 92-103, 2011.

[67] Bizzarri G, Morini GL. "New technologies for an effective energy retrofit of hospitals". Applied Thermal Engineering, 26, 161-169, 2006.

[68] Ruan Y, Liu Q, Zhou W, Firestone R, Gao W, Watanabe T. "Optimal option of distributed generation technologies for various commercial buildings". Applied Energy, 86, 1641-1653, 2009.

[69] Bizzarri G. "On the size effect in PAFC grid-connected plant". Applied Thermal Engineering, 26, 1001-1007, 2006.

[70] Rasouli M, Akbari S, Simonson CJ, Besant RW. "Energetic, economic and environmental analysis of a health-care facility HVAC system equipped with a run-around membrane energy exchanger". Energy and Buildings, 69, 112-121, 2014.

[71] Buonomano A, Calise F, Ferruzzi G, Palombo A. "Dynamic energy performance analysis: Case study for energy efficiency retrofits of hospital buildings". Energy, 78, 555-572, 2014.

[72] Principi P, Fioretti R, Carbonari A, Lemma M. "Evaluation of energy conservation opportunities through Energy Performance Contracting: A case study in Italy". Energy and Buildings, 128, 886-899, 2016. 
[73] Mohammadpour A, Anumba CJ, Messner JI. "Integrated Framework for Patient Safety and Energy Efficiency in Healthcare Facilities Retrofit Projects". Health Environments Research and Design Journal, 9, 68-85, 2016.

[74] Saidur R, Hasanuzzaman M, Yogeswaran S, Mohammed H.A, Hossain M.S. "An end-use energy analysis in a Malaysian public hospital". Energy, 35, 4780-4785, 2010.

[75] Morgenstern P, Li M, Raslan R, Ruyssevelt P, Wright A. "Benchmarking acute hospitals: Composite electricity targets based on departmental consumption intensities". Energy and Buildings, 118, 277-290, 2016.

[76] Kramer L, Rizzo V. "Development of a Comprehensive Energy Evaluation Program For a Medical Center in the Northeast: A Case Study. Energy Engineering". Journal of the Association of Energy Engineers, 112(2), 57-79, 2015.

[77] Karakasli E, Oztop HF, Hepbasli A. "Performance assessment of a polyclinic heating and cooling system in a hospital building". International Journal of Exergy, 21, 70-86, 2016.

[78] Khodakarami J, Knight I, Nasrollahi N. "Reducing the demands of heating and cooling in Iranian hospitals". Renewable Energy, 34, 1162-1168, 2009.

[79] Alexis GK, Liakos P. "A case study of a cogeneration system for a hospital in Greece. Economic and environmental impacts". Applied Thermal Engineering, 54, 488-496, 2013.

[80] Ziher D, Poredos A. "Economics of a trigeneration system in a hospital". Applied Thermal Engineering, 26, 680-687, 2006.

[81] Cardona E, Piacentino A, Cardona F. "Matching economical, energetic and environmental benefits: An analysis for hybrid CHCP-heat pump systems". Energy Conversion and Management, 47, 3530-3542, 2006.

[82] Bujak J. "Heat consumption for preparing domestic hot water in hospitals". Energy and Buildings, 42, 1047-1055, 2010.

[83] Murray J, Pahl 0, Burek S. "Evaluating the scope for energy-efficiency improvements in the public sector: Benchmarking NHSScotland's smaller health buildings". Energy Policy, 36(3), 1236-1242, 2008.

[84] Carbonari A, Fioretti R, Lemma M, Principi P. "Managing energy retrofit of acute hospitals and community clinics through EPC contracting: the MARTE Project". Energy Procedia, 78, 1033-1038, 2015.

[85] Capozzoli A, Piscitelli MS, Neri F, Grassi D, Serale G. “A novel methodology for energy performance benchmarking of buildings by means of Linear Mixed Effect Model: The case of space and DHW heating of outpatient Healthcare Centres". Applied Energy, 171, 592-607, 2016.

[86] Sanz-Calcedo JG, Blázquez FC, Rodríguez FL, "Ruiz-Celma A. Influence of the number of users on the energy efficiency of health centres". Energy and Buildings, 43, 1544-1548, 2011.

[87] Bujak J. "Mathematical modelling of a steam boiler room to research thermal efficiency". Energy, 33, 1779-1787, 2008.

[88] Yun H, Li W. "Optimization and Analysis of Distributed Energy System with Energy Storage Device". Energy Procedia, 12, 958-965, 2011.
[89] Cardona E, Piacentino E. "A new approach to exergoeconomic analysis and design of variable demand energy systems". Energy, 31, 490-515, 2006.

[90] Tsoutsos T, Aloumpi E, Gkouskos Z, Karagiorgas M. "Design of a solar absorption cooling system in a Greek hospital". Energy and Buildings, 42, 265-272, 2010.

[91] Ahmadzadehtalatapeh M, Yau YH. "The application of heat pipe heat exchangers to improve the air quality and reduce the energy consumption of the air conditioning system in a hospital ward-a full year model simulation". Energy and Buildings, 43, 2344-2355, 2011.

[92] Vanhoudt D, Desmedt J, Van Bael J, Robeyn N, Hoes H. “An aquifer thermal storage system in a Belgian hospital: Long-term experimental evaluation of energy and cost savings". Energy and Buildings, 43, 3657-3665, 2011.

[93] Ascione F, Bianco N, De Masi RF, Vanoli GP. "Rehabilitation of the building envelope of hospitals: Achievable energy savings and microclimatic control on varying the HVAC systems in Mediterranean climates". Energy and Buildings, 60, 125-138, 2013.

[94] Congradac V, Prebiracevic B, Petrovacki N. "Methods for assessing energy savings in hospitals using various control techniques". Energy and Buildings, 69, 85-92, 2014.

[95] Boschiero do Espirito Santo D. "An energy and exergy analysis of a high-efficiency engine trigeneration system for a hospital: A case study methodology based on annual energy demand profiles". Energy and Buildings, 76, 185-198, 2014.

[96] Silveira JL, Lamas WdQ, Tuna CE, Villela IAdC, Miro LS. "Ecological efficiency and thermoeconomic analysis of a cogeneration system at a hospital". Renewable and Sustainable Energy Reviews, 1, 2894-2906, 2012.

[97] Moradi MH, Hajinazari M, Jamasb S, Paripour M. "An energy management system (EMS) strategy for combined heat and power (CHP) systems based on a hybrid optimization method employing fuzzy programming". Energy, 49, 86-101, 2013.

[98] Rezvan AT, Gharneh NS, Gharehpetian GB. "Optimization of distributed generation capacities in buildings under uncertainty in load demand". Energy and Buildings, 57, 58-64, 2013.

[99] Zhou N, Marnay C, Firestone R, Gao W, Nishida M. “An analysis of the DER adoption climate in Japan using optimization results for prototype buildings with US. Comparisons". Energy and Buildings, 38, 1423-1433. 2006.

[100] Rey FJ, Velasco E, Varela F. "Building energy analysis (BEA): A methodology to assess building energy labelling". Energy and Buildings, 39, 709-716, 2007.

[101] Medrano M, Brouwer J, McDonell V, Mauzey J, Samuelsen S. "Integration of distributed generation systems into generic types of commercial buildings in California". Energy and Buildings, 40, 537-548, 2008.

[102] Fernández MA, Zorita AL, García-Escudero LA, Duque O, Moríñigo D, Riesco M, Muñoz M. "Cost optimization of electrical contracted capacity for large customers". International Journal of Electrical Power and Energy Systems, 46, 123-131, 2013.

[103] Tulsyan A, Dhaka S, Mathur J, Yadav JV. "Potential of energy savings through implementation of Energy Conservation Building Code in Jaipur city, India". Energy and Buildings, 58, 123-130, 2013. 
[104] García-Sanz-Calcedo J, López-Rodríguez F, Cuadros F. "Quantitative analysis on energy efficiency of health centers according to their size". Energy and Buildings, 73, 7-12, 2014.

[105] Çakir U, Çomakli K, Yüksel F. "The role of cogeneration systems in sustainability of energy". Energy Conversion and Management, 63, 192-202, 2012.

[106] Facci AL, Anreassi L, Martini F, Ubertini S. "Comparing energy and cost optimization in distributed energy systems management". Journal of Energy Resources Technology, Transactions of the ASME, 136(3), 032001, 2014.

[107] Chung M, Park HC. "Comparison of building energy demand for hotels, hospitals, and offices in Korea". Energy, 92, 383-393, 2015.

[108] Morgenstern P, Raslan R, Huebner G. "Applicability, potential and limitations of staff-centred energy conservation initiatives in English hospitals". Energy Efficiency, 9, 27-28, 2016.

[109] Moghimi S, Azizpour F, Mat S, Lim CH, Salleh E, Sopian $\mathrm{K}$. "Building energy index and end-use energy analysis in large-scale hospitals-case study in Malaysia". Energy Efficiency, 7, 243-256, 2014.

[110] Radulovic D, Skok S, Kirincic V. "Cogeneration e Investment dilemma". Energy, 48, 177-187, 2012.

[111] Briller DL. "Patients and Urgency: Strategies for Designing Sustainable and Energy-efficient Hospitals For the 21 $1^{\text {st }}$ Century. Energy Engineering". Journal of the Association of Energy Engineers, 111(6), 22-80, 2014.

[112] Basken B, Galloni P. "Successful Low-cost Energy Management Implementation in Healthcare Facilities". Energy Engineering: Journal of the Association of Energy Engineers, 111(5), 35-50, 2014.

[113] Laitner JA, Hanson DA. "Modeling detailed energyefficiency technologies and technology policies within a CGE framework". Energy Journal, 27, 151-169, 2006.

[114] Ahmed TMF, Rajagopalan P, Fuller R. "A classification of healthcare facilities: Toward the development of energy performance benchmarks for day surgery centers in Australia". Health Environments Research and Design Journal, 8(4), 139-157, 2015.

[115] Burpee H, McDade E. "Comparative Analysis of Hospital Energy Use: Pacific Northwest and Scandinavia". Health Environments Research and Design Journal, 8, 20-44, 2014.

[116] Teke A, Timur 0, Bayındır KÇ, "Development and testing of an energy saving tool-Suitability analysis with case study". International Journal of Electrical Power and Energy Systems, 77, 59-69, 2016.

[117] Pradhan AK, Kar SK, Mohanty MK. "Off-grid renewable hybrid power generation system for a public health centre in rural village". International Journal of Renewable Energy Research, 6, 282-288, 2016.

[118] Okamoto S. "Saving energy in a hospital utilizing CCHP technology". International Journal of Energy and Environmental Engineering, 2(2), 45-55, 2011.

[119] Zheng CY, Wu JY, Zhai XQ, Wang RZ. "Impacts of feed-in tariff policies on design and performance of CCHP system in different climate zones". Applied Energy, 175, 168-179, 2016.

[120] Rohde T, Martinez R. "Equipment and energy usage in a large teaching hospital in norway". Journal of Healthcare Engineering, 6(3), 419-434, 2015.
[121] García-Sanz-Calcedo J. "Analysis on energy efficiency in healthcare buildings". Journal of Healthcare Engineering, 5(3), 361-374, 2014.

[122] Rajagopalan P, Elkadi H. "Energy performance of medium-sized healthcare buildings in Victoria, Australia- A case study". Journal of Healthcare Engineering, 5(2), 247-260, 2013.

[123] Teke A, Zor K, Timur O. "A simple methodology for capacity sizing of cogeneration and trigeneration plants in hospitals: A case study for a university hospital". Journal of Renewable and Sustainable Energy, 7(5), 053102, 2015.

[124] Teke A, Timur 0. "Assessing the energy efficiency improvement potentials of HVAC systems considering economic and environmental aspects at the hospitals". Renewable and Sustainable Energy Reviews, 33, 224-235, 2014

[125] Christiansen N, Kaltschmitt M, Dzukowski F, Isensee F. "Electricity consumption of medical plug loads in hospital laboratories: Identification, evaluation, prediction and verification". Energy and Buildings, 107, 392-406. 2015.

[126] Zhang J, Cho H, Knizley A. "Evaluation of financial incentives for combined heat and power (CHP) systems in U.S. Regions". Renewable and Sustainable Energy Reviews, 59, 738-762, 2016.

[127] Moghimi S, Bakhtyar B, Azizpour F, Sopian K, Lim CH, Mat S, Salleh E. "Maximization of energy saving and minimization of insulation cost in a tropical hospital: A case study in Malaysia". WSEAS Transactions on Environment and Development, 9, 105-115, 2013.

[128] Zorita AL, Fernández-Temprano MA, García-Escudero LA, Duque-Perez O. "A statistical modeling approach to detect anomalies in energetic efficiency of buildings". Energy and Buildings, 110, 377-386, 2016.

[129] Chicco G, Mancarella P. "From cogeneration to trigeneration: Profitable alternatives in a competitive market". IEEE Transactions on Energy Conversion, 21, 265-272, 2006

[130] Mago PJ, Luck R. "Prime mover sizing for base-loaded combined heating and power systems". Proceedings of the Institution of Mechanical Engineers, Part A: Journal of Power and Energy, 226, 17-27, 2012.

[131] Misa T, Crisford M, Jain S, Bansal PK. "Thermodynamic analysis of an in-situ cogeneration plant". Proceedings of the Institution of Mechanical Engineers, Part A: Journal of Power and Energy, 221, 591-602, 2007.

[132] Zheng C, Zhai X, Wu J, Yang G. "Modeling of CCHP system and analysis of thermal storage strategy by using TRNSYS software". Huagong Xuebao/CIESC Journal, 66, 311-317, 2015.

[133] Esmaeili MA, Jahromi AS, Twomey J, Yildirim B, Overcash M, Dominquez F, Thomas N, Mcadam A. "Hospital radiology department overhead energy estimation". Proceedings of the 2011 IEEE International Symposium on Sustainable Systems and Technology, ISSST, USA, 16-18 May 2011.

[134] Gordo E, Campos A, Coelho D. "Energy efficiency in a hospital building case study: Hospitais da universidade de Coimbra". Proceedings of the $20113^{\text {rd }}$ International Youth Conference on Energetics, IYCE, Portugal, 7-9 July 2011. 
[135] Machado CML, Scavarda A, Zhao F, Kipper LM. "A proposal of an energy saving technology framework for the hospital". Chemical Engineering Transactions, 45, 241-246, 2015.

[136] Alhurayess S, Darwish MK. "Analysis of energy management in hospitals". Proceedings of the Universities Power Engineering Conference, UK, 4-7 September 2012.

[137] Serra LM, Lozano MA, Carvalho M. "Evaluation of environmental loads for the synthesis of a trigeneration system". ASME 2010 4th International Conference on Energy Sustainability, ES, USA, 17-22 May 2010.

[138] Vocale P, Pagliarini G, Rainieri S. ace "Space Heating Load Estimation Procedure for CHP Systems sizing". Journal of Physics: Conference Series; Italy, 22-24 June 2015.

[139] Sanz-Calcedo JG, Cuadros-Blázquez F, Ruiz-Celma A, López-Rodríguez F. "Efficiency of a biomass boiler in a hospital center". Use of olive crushing stones to produce heat. Dyna (Spain), 86, 343-349, 2011.

[140] Dos Santos JB, Jabbour CJC. "Critical factors to be considered when planning the implementation of environmental improvements and energy saving". Journal of Energy in Southern Africa, 24, 22-29, 2013.

[141] Thongkaw S, Assawamartbunlue K. "Energy utilization index and benchmarking for a government hospital". Kasetsart Journal-Natural Science 46, 298-304, 2012.

[142] Kazem HA, Ali SQ, Alwaeli AHA, Mani K, Tariq M. "Lifecycle cost analysis and optimization of health clinic PV system for a rural area in Oman". Lecture Notes in Engineering and Computer Science, 2, 1052-1056, 2013.

[143] Nwanya SC, Sam-Amobi C, Ekechukwu OV. "Energy performance indices for hospital buildings in Nigeria". International Journal of Technology, 7, 15-25, 2016.

[144] Bilton A, Kelley L, Mazzini F. "Design optimization of sustainable off-grid power systems for the developing World". ASME 2011 5th International Conference on Energy Sustainability, ES; USA, 7-10 August 2011.

[145] Law YLE, Dworkin SB. "Characterization of the effects of borehole configuration and interference with long term ground temperature modelling of ground source heat pumps". Applied Energy, 2016, 179, 1032-1047.

[146] Howard B, Modi V. "Examination of the optimal operation of building scale combined heat and power systems under disparate climate and GHG emissions rates". Applied Energy, 185, 280-293, 2017.

[147] Cheung H, Braun JE. "Empirical modeling of the impacts of faults on water-cooled chiller power consumption for use in building simulation programs". Applied Thermal Engineering; 99, 756-764, 2016.

[148] Li MJ, Zhao W, Chen X, Tao WQ. "Economic analysis of a new class of vanadium redox-flow battery for mediumand large-scale energy storage in commercial applications with renewable energy". Applied Thermal Engineering, 114, 802-814, 2017.

[149] El-Maghlany WM, ElHefni AA, ElHelw M, Attia A. "Novel air conditioning system configuration combining sensible and desiccant enthalpy wheels". Applied Thermal Engineering, 127, 1-15, 2017.

[150] Christiansen N, Kaltschmitt M, Dzukowski F. "Electrical energy consumption and utilization time analysis of hospital departments and large scale medical equipment". Energy and Buildings; 131, 172-183, 2016.
[151] Buonomano A, Montanaro U, Palombo A, Santini S. "Temperature and humidity adaptive control in multienclosed thermal zones under unexpected external disturbances". Energy and Buildings, 135, 263-285, 2017.

[152] Ma H, Du N, Yu S, Lu W, Zhang Z, Deng N, Li C. “Analysis of typical public building energy consumption in northern China". Energy and Buildings, 136, 139-150, 2017.

[153] Dutta A, Samanta A, Neogi S. "Influence of orientation and the impact of external window shading on building thermal performance in tropical climate". Energy and Buildings, 139, 680-689, 2017.

[154] Biglia A, Carreda FV, Fabrizio E, Filippi M, Mandas N. "Technical-economic feasibility of CHP systems in large hospitals through the Energy Hub method: The case of Cagliari AOB". Energy and Buildings, 147, 101-112, 2017.

[155] Lan L, Tushar W, Otto K, Yuen C, Wood KL. "Thermal comfort improvement of naturally ventilated patient wards in Singapore". Energy and Buildings, 154, 499512, 2017.

[156] Gimelli A, Muchillo M, Sannino R. "Optimal design of modular cogeneration plants for hospital facilities and robustness evaluation of the results". Energy Conversion and Management, 134, 20-31, 2017.

[157] Arabkoohsar A, Andresen GB. "Supporting district heating and cooling networks with a bifunctional solar assisted absorption chiller". Energy Conversion and Management, 148, 184-196, 2017.

[158] Chaichaloempreecha A, Winyuchakrit P, Limmeechokchai B. "Long-term energy savings and GHG mitigations in Thailand's building sector: impacts of energy efficiency plan". Energy Procedia, 138, 847-852, 2017.

[159] Thinate N, Wongsapai W, Damrongsak D. "Energy performance study in thailand hospital building". Energy Procedia, 141, 255-259, 2017.

[160] Calise F, d'Accadia MD, Libertini L, Quiriti E, Vicidomini M. "A novel tool for thermoeconomic analysis and optimization of trigeneration systems: A case study for a hospital building in Italy". Energy, 126, 64-87, 2017.

[161] Carnero MC, Gomez A. "Maintenance strategy selection in electric power distribution systems". Energy, 129, 255-272, 2017.

[162] Pizzolato A, Donato F, Verda V, Santarelli M, Sciacovelli A. "CSP plants with thermocline thermal energy storage and integrated steam generator e technoeconomic modeling and design optimization". Energy, 139, 231-246, 2017.

[163] Bagnasco A, Catanzariti R, Coppi L, Fresi F, Silvestro F, Vinci A. "Multi facility energy monitoring in medical structures: Defining KPIs for energy saving and exporting best practices". International Journal of Heat and Technology, 35, 214-220, 2017.

[164] Ahmed TMF, Rajagopalan P, Fuller R. "Experimental validation of an energy model of a day surgery/procedure centre in Victoria". Journal of Building Engineering, 10, 1-12, 2017. 
[165] Bertone E, Sahin O, Stewart RA, Zou PXW, Alam M, Hampson K, Blair E. "Role of financial mechanisms for accelerating the rate of water and energy efficiency retrofits in Australian public buildings: Hybrid bayesian network and system dynamics modelling approach". Applied Energy, 210, 409-419, 2018.

[166] Zhang J, Cho H, Luck R, Mago PJ. "Integrated photovoltaic and battery energy storage (PV-BES) systems: An analysis of existing financial incentive policies in the US". Applied Energy, 212, 895-908, 2018.

[167] Orosz M, Altes-Buch Q, Mueller A, Lemort V. "Experimental validation of an electrical and thermal energy demand model for rapid assessment of rural health centers in sub-Saharan Africa". Applied Energy, 218, 382-390, 2018.

[168] Ahn H, Rim D, Freihaut JD. "Performance assessment of hybrid chiller systems for combined cooling, heating and power production". Applied Energy, 225, 501-512, 2018.

[169] Luo S, Li H, Mao Y, Yang C. "Experimental research on a novel sun shading \& solar energy collecting, coupling device for inpatient building in hot summer and cold winter climate zone in China". Applied Thermal Engineering, 142, 89-99, 2018.

[170] Gonzalez AG, García-Sanz-Calcedo J, Salgado DR. "Evaluation of Energy Consumption in German Hospitals: Benchmarking in the Public Sector". Energies, 11, 2279, 2018.

[171] Gordillo-Orquera R, Muñoz-Romero S, Arcos-Aviles D, Chillón R, Lopez-Ramos LM, Marques AG, Rojo-Álvarez JL. "Convex programming and bootstrap sensitivity for optimized electricity bill in healthcare buildings under a time-of-use pricing scheme". Energies, 11(6), 1454, 2018.

[172] Park SK, Moon HJ, Min KC, Hwang C, Kim S. "Application of a multiple linear regression and an artificial neural network model for the heating performance analysis and hourly prediction of a large-scale ground source heat pump system". Energy and Buildings, 165, 206-215, 2018.
[173] Giretti A, Vaccarini M, Casals M, Macarulla M, Fuertes A, Jones RV. "Reduced-order modeling for energy performance contracting". Energy and Buildings, 167, 216-230, 2018.

[174] González-Gil A, López-González JL, Fernández M, Eguía P, Erkoreka A, Granada E. "Thermal energy demand and potential energy savings in a Spanish surgical suite through calibrated simulations". Energy and Buildings, 174, 513-526, 2018

[175] Urbanucci L, Testi D. “Optimal integrated sizing and operation of a CHP system with Monte Carlo risk analysis for long-term uncertainty in energy demands". Energy Conversion and Management, 157, 307-316, 2018.

[176] Cesari S, Valdiserri P, Coccaggna M, Mazzacane S. "Energy savings in Hospital patient rooms: the role of windows size and glazing properities". Energy Procedia, 148, 1151-1158, 2018.

[177] Noussan M, Jarre M. "Multicarrier energy systems: Optimization model based on real data and application to a case study". International Journal of Energy Research, 42, 1338-1351, 2018.

[178] Lee J, Ryu SH, Kim D. "Role of ICT in enhancing energy efficiency of commercial buildings: Case study of optimized energy control system in hospital "p"". Journal of Renewable and Sustainable Energy, 10, 025101, 2018.

[179] Isa NM, Tan CW, Yatim AHM. "A comprehensive review of cogeneration system in a microgrid: A perspective from architecture and operating system". Renewable and Sustainable Energy Reviews, 81, 2236-2263, 2018.

[180] Arabkoohsar A, Andresen GB. "A smart combination of a solar assisted absorption chiller and a power productive gas expansion unit for cogeneration of power and cooling". Renewable Energy, 115, 489-500, 2018.

[181] Zhao BY, Li Y, Wang RZ, Zhao ZG, Taylor RA. "A universal method for performance evaluation of solar photovoltaic air-conditioner". Solar Energy, 172, 58-68, 2018. 